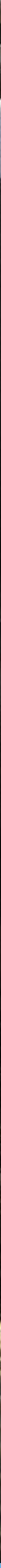

Fosfaatvormen in melkveemest en potentieel voor terugwinning

M. Timmerman, I.C. Regelink, N. Verdoes, G. Kupers en K. Blanken. 



\title{
Fosfaatvormen in melkveemest en potentieel voor terugwinning
}

M. Timmerman ${ }^{1)}$, I.C. Regelink ${ }^{2)}$, N. Verdoes ${ }^{1)}, \mathrm{G}$, Kupers ${ }^{1)}$, K. Blanken ${ }^{1)}$

\author{
1 Wageningen Livestock Research \\ 2 Wageningen Environmental Research
}

Dit onderzoek is uitgevoerd door Wageningen Livestock Research, in opdracht van en gefinancierd door het Ministerie van Economische Zaken, in het kader van het Kennisbasisonderzoek thema 'Circular \& Biobased Economy' (projectnummer KB-26-010-002) en het thema 'Resource Use Efficiency' (projectnummer KB-30-002-009).

Wageningen Livestock Research

Wageningen, Februari 2018

Rapport 1087 

Timmerman, M., I.C. Regelink, N. Verdoes, G. Kupers, K. Blanken, 2017. Fosfaatvormen in melkveemest en potentieel voor terugwinning. Wageningen Livestock Research, Rapport 1087.

Samenvatting NL In dit rapport zijn de resultaten beschreven van het onderzoek naar fosfaatvormen en potentieel van fosfaatterugwinning uit melkveemest. Op verschillende melkveebedrijven met verschillende type mestscheiders en uitmestsystemen zijn monsters genomen van de drijfmest, dunne fractie, dikke fractie en/of faeces en geanalyseerd op de gehalten aan verschillende fosfaatvormen. Aanvullend is calciumhydroxide $\left(\mathrm{Ca}(\mathrm{OH})_{2}\right)$ aan de dunne fracties toegevoegd om het orthofosfaat met het sediment te kunnen afscheiden en zijn de dikke fracties verdund en aangezuurd tot pH 6 en 5 om te bepalen hoeveel fosfaat vrijkomt als orthofosfaat. Op basis van deze analyses is het potentieel voor fosfaatterugwinning bepaald.

Summary UK This report describes the results of the research into the phosphate forms and the potential of recovery of phosphate from dairy manure. On different dairy farms with different types of manure separators, slurry robots and scrapers samples were taken from the manure, liquid fraction, thick fraction and/or faeces and analyzed on the content of different phosphate forms. Furthermore calcium hydroxide was added to the liquid fraction to separate the orthophosphate with the sediment and are the thick fractions diluted and acidified to $\mathrm{pH} 6$ and 5 to determine the amount of phosphate being released as orthophosphate. On the basis of these analysis is the potential for recovery of phosphate determined.

Dit rapport is gratis te downloaden op https://doi.org/10.18174/442094 of op www.wur.nl/livestock-research (onder Wageningen Livestock Research publicaties).

\section{(C) 2018 Wageningen Livestock Research}

Postbus 338, 6700 AH Wageningen, T 03174839 53, E info.livestockresearch@wur.nl, www.wur.nl/livestock-research. Wageningen Livestock Research is onderdeel van Wageningen University \& Research.

Wageningen Livestock Research aanvaardt geen aansprakelijkheid voor eventuele schade voortvloeiend uit het gebruik van de resultaten van dit onderzoek of de toepassing van de adviezen.

Alle rechten voorbehouden. Niets uit deze uitgave mag worden vermenigvuldigd en/of openbaar gemaakt worden door middel van druk, fotokopie, microfilm of op welke wijze dan ook zonder voorafgaande toestemming van de uitgever of auteur.

De certificering volgens ISO 9001 door DNV onderstreept ons kwaliteitsniveau. Op als onze onderzoeksopdrachten zijn de Algemene Voorwaarden van de Animal Sciences Group van toepassing. Deze zijn gedeponeerd bij de Arrondissementsrechtbank Zwolle. 



\section{Inhoud}

$\begin{array}{ll}\text { Samenvatting } & 5\end{array}$

1

$\begin{array}{ll}\text { Inleiding } & 7\end{array}$

$\begin{array}{lll}1.1 & \text { Achtergrond } & 7\end{array}$

$\begin{array}{lll}1.2 & \text { Doel } & 7\end{array}$

2

$\begin{array}{ll}\text { Materiaal en Methode } & 8\end{array}$

2.1 Materiaal $\quad 8$

2.2 Monsternamemethode 9

2.3 Analysemethoden 9

2.3.1 Mestanalyses 9

2.3.2 Analyse van fosfaatvormen in dunne fractie van mest 10

2.3.3 Terugwinning van fosfaat uit de dunne fractie $\quad 11$

2.3.4 Terugwinning van fosfaat uit de dikke fractie $\quad 11$

3

$\begin{array}{ll}\text { Resultaten } & 12\end{array}$

3.1 Vergelijking analysemethoden orthofosfaat $\quad 12$

$\begin{array}{lll}3.2 & \text { Samenstelling drijfmest } & 13\end{array}$

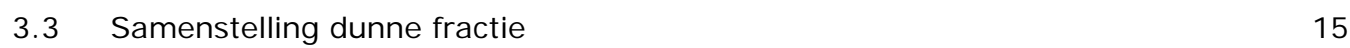

$\begin{array}{lll}3.4 & \text { Samenstelling dikke fractie } & 18\end{array}$

$\begin{array}{lll}3.5 & \text { Samenstelling faeces } & 20\end{array}$

3.6 Terugwinning van fosfaat uit de dunne fractie $\quad 22$

$\begin{array}{lll}3.7 & \text { Terugwinning van fosfaat uit de dikke fractie } & 23\end{array}$

4

Discussie 



\section{Samenvatting}

De melkveehouderij heeft nadrukkelijk te maken met de fosfaatregelgeving. Veel melkveebedrijven hebben te maken met een fosfaatoverschot en zullen een deel van hun fosfaat moeten afvoeren. Afzet van fosfaat in de vorm van drijfmest gaat gepaard met hoge transportkosten omdat drijfmest voor meer dan $90 \%$ bestaat uit water. Om de transportkosten terug te dringen is er vraag naar methoden en technieken waarmee het fosfaat uit de mest afgescheiden kan worden en verwerkt kan worden tot een geconcentreerd bemestingsproduct zodat afzet over grotere afstanden economisch haalbaar wordt. De resterende fosfaatverarmde mest kan vervolgens op eigen grond gebruikt worden.

Het doel van het onderzoek was te bepalen in welke vorm fosfaat aanwezig is in melkveemest en om daarmee het potentieel van afscheiding en terugwinning van fosfaat uit melkveemest te bepalen. Om het winningspotentieel in beeld te brengen zijn in dit onderzoek drie groepen onderscheiden:

- Orthofosfaat (i.e. het daadwerkelijk opgeloste orthofosfaat $\left(\mathrm{PO}_{4}{ }^{3-}, \mathrm{HPO}_{4}{ }^{2-}\right.$, etc.),

- Mineraal fosfaat (o.a. calciumfosfaat, struviet),

- Organisch fosfaat (o.a. fytaat, celwanden, fosfolipiden, etc.).

Het onderzoek is uitgevoerd op melkveebedrijven met een mestscheider of uitmestsystemen die de faeces van de roostervloer weghalen. Op de bedrijven zijn de volgende typen mestscheiders gebruikt voor het scheiden van de mest: vijzelpers, trommelscheider, rollenpers of decanter. Per type mestscheider zijn twee of drie melkveebedrijven bezocht en zijn monsters genomen van de drijfmest, dunne en dikke fractie. Op twee melkveebedrijven met een stalreinigingsrobot en één bedrijf met een mestschuif zijn mestmonsters genomen van de faeces. De drijfmesten en dikke fracties zijn geanalyseerd op de gehalten aan fosfaat en orthofosfaat. Aanvullend zijn de dikke fracties verdund en aangezuurd tot pH 6 en 5 om te bepalen hoeveel fosfaat vrijkomt als orthofosfaat. De dunne fracties zijn geanalyseerd op het gehalten aan orthofosfaat, mineraal fosfaat, organisch fosfaat en totaal fosfaat. Aanvullend is calciumhydroxide $\left(\mathrm{Ca}(\mathrm{OH})_{2}\right)$ aan de dunne fracties toegevoegd om het orthofosfaat met het sediment te kunnen afscheiden.

Het uitgevoerde onderzoek heeft de volgende resultaten opgeleverd:

- Het fosfaatgehalte in de dikke fracties uit de mestscheiders varieerde van 1,21 tot 4,29 g/ kg en was het hoogst in dikke fractie van de centrifuge. Het fosfaatgehalte in de dunne fracties uit de mestscheiders varieerde van 0,25 tot $1,88 \mathrm{~g} / \mathrm{kg}$ en waren het laagst in de dunne fracties van de centrifuge.

- Het aandeel orthofosfaat in de drijfmest, dikke fracties en faeces maakte een klein deel $(<8 \%)$ uit van de totale hoeveelheid fosfaat.

- Het aandeel orthofosfaat in de dunne fractie was minder dan $4 \%$ van de totale hoeveelheid fosfaat. Het aandeel mineraal fosfaat varieerde van 43 tot $81 \%$ van de totale fosfaat in de dunne fractie en organische fosfaat voor 18 tot $53 \%$.

- $\quad \mathrm{Na}$ toevoeging van calciumhydroxide aan de dunne fracties en centrifugeren kwam $23 \%$ van de massa, $54 \%$ van de drogestof, $83 \%$ van het totaal fosfaat en $36 \%$ van de orthofosfaat terecht in het sediment.

- $\quad$ Door de dikke fractie te verdunnen tot $6 \%$ drogestof en aan te zuren tot pH 6 komt 40 tot $59 \%$ van de totale hoeveelheid fosfaat beschikbaar als orthofosfaat. Dit aandeel neemt toe naar $42 \%$ tot $68 \%$ bij verder aanzuren tot $\mathrm{pH} 5$.

- Het potentieel voor winning van fosfaat uit de drijfmest, faeces, dunne of dikke fractie is laag vanwege de lage orthofosfaat gehalten in deze mestsoorten. Het potentieel kan worden verhoogd door verdunnen en/of aanzuren van de mestfracties waardoor additioneel orthofosfaat vrijkomt uit de minerale fosfaatverbindingen. 


\section{$1 \quad$ Inleiding}

\section{$1.1 \quad$ Achtergrond}

Fosfor $(P)$ is een essentieel element voor al het leven op aarde. Het inefficiënt gebruik van fosfor, in het bijzonder in de voedselketen, leidt tot af- en uitspoeling van fosfaat $\left(\mathrm{P}_{2} \mathrm{O}_{5}\right)$ naar grond- en oppervlaktewater en vormt daarmee een bedreiging voor het aquatisch milieu. Inefficiënt gebruik van fosfaat zorgt daarnaast voor uitputting van de beschikbare rots-fosfaat wat een essentiële eindige natuurlijke hulpbron is die in een beperkt aantal landen beschikbaar is. Een hogere fosfaat-efficiëntie is dus essentieel om fosfaat voor toekomstige generaties beschikbaar te houden en om ons milieu te beschermen. In bijlage 1 staan de fosforstromen voor Nederland weergegeven over 2011. Deze laten zien dat over 2011 in Nederland een verlies van in totaal 23 miljoen kg P optrad, met name door het niet hergebruiken van fosfor uit zuiveringsslib van RWZI's en andere afvalstromen. In de Nederlandse landbouw gaat daarnaast nog eens 3 miljoen $\mathrm{kg} P$ verloren door uit- of afspoeling naar het grond- en oppervlaktewater en accumuleert 12 miljoen $\mathrm{kg} P$ in de bodem. Dit illustreert dat er grote verbeteringen mogelijk zijn om de fosforefficiëntie in Nederland te verhogen. De fosforefficiëntie kan worden verbeterd door het reduceren van fosfor verliezen en door hergebruik van fosfor uit reststromen (voedsel afval, dierlijke mest, menselijke mest), zonder dat dit de kwaliteit van de bodem en de voedselveiligheid negatief beïnvloedt. Dit vereist een combinatie van innovatieve en duurzame technologieën om: 1) de fosforefficiëntie op boerderijschaal en regionaal niveau te verbeteren, 2) reststromen te recyclen en 3 ) fosfor te winnen uit reststromen om fosfaatkunstmest en andere minerale fosfor substituten te produceren.

De fosfaatgebruiksnormen bepalen dat de toegestane fosfaatbemesting beperkt is tot evenwichtsbemesting. In 2016 was het totale fosfaataanbod vanuit dierlijke mest $25 \%$ hoger dan de totale plaatsingsruimte voor fosfaat in de Nederlandse landbouw waardoor op jaarbasis circa 40 miljoen kg fosfaat geëxporteerd moest worden (Koeijer et al., 2017). Ook de melkveehouderij heeft nadrukkelijk te maken met de fosfaatregelgeving: fosfaatgebruiksnormen, fosfaatrechten, melkveewet (met AMvB grondgebondenheid), nationaal fosfaatplafond en de verplichte mestverwerking.

Veel melkveebedrijven hebben te maken met een fosfaatoverschot en zullen een deel van hun fosfaat moeten afvoeren. Het aandeel melkveemest dat niet op het eigen bedrijf geplaatst kan worden, wordt veelal afgezet naar de akkerbouw. Afzet van fosfaat in de vorm van drijfmest gaat gepaard met hoge transportkosten omdat drijfmest voor meer dan $90 \%$ bestaat uit water. Om de transportkosten terug te dringen is er vraag naar methoden en technieken waarmee het fosfaat uit de mest afgescheiden kan worden en verwerkt kan worden tot een geconcentreerd product zodat afzet over grotere afstanden economisch haalbaar wordt. De resterende fosfaatverarmde mest kan vervolgens op eigen grond gebruikt worden.

\subsection{Doel}

Het doel van het onderzoek was te bepalen in welke vorm fosfaat aanwezig is in melkveemest en om daarmee het potentieel van afscheiding en terugwinning van fosfaat uit melkveemest te bepalen. 


\section{Materiaal en Methode}

Het potentieel van terugwinning fosfaat uit dikke en dunne fractie van melkveemest is door middel van laboratorium proeven onderzocht. Hiervoor zijn twee methoden onderzocht; (i) terugwinning van fosfaat uit de dunne mestfractie in de vorm van calciumfosfaat door dosering van calciumhydroxide en (ii) zuurextractie van fosfaat uit de dikke fractie gevolgd door scheiding en dosering van calciumhydroxide (zuur-base spoor). Om de potentie van deze methoden te beoordelen is het van belang om de fosfaatgehalten en fosfaatvormen in de dikke en dunne fracties van melkveemest te kennen. Omdat de perspectieven van beide terugwinningsmethoden samenhangen met de fosfaatgehalten in de dunne dan wel dikke fractie van de mest is tevens behoefte aan kennis over fosfaatgehalten in relatie tot scheidingstechnieken.

\section{$2.1 \quad$ Materiaal}

Het onderzoek is uitgevoerd in de maanden september, oktober en november op melkveebedrijven met een mestscheider of met uitmestsystemen (stalreinigingsrobot, mestschuif) die de faeces snel van de roostervloer halen waardoor een scheiding optreedt tussen urine en faeces. Er zijn onderscheidende typen melkveebedrijven gekozen om zo een beeld te krijgen van de variatie die optreedt in fosfaat en orthofosfaat gehalten in de praktijk. Dit is gebeurd door bedrijven te bezoeken die verschilden qua rantsoensamenstelling zoals het aandeel (kuil)gras, aandeel mais en/of fosfaatgehalte in het totaal rantsoen. De rantsoensamenstelling wat gevoerd werd voorafgaand aan de monstername staat weergegeven in tabel 1, welke afkomstig waren van de rantsoenberekening van de voeradviseur van het bedrijf.

Tabel 1 Rantsoensamenstelling en gehalten aan fosfor en ruw eiwit in het rantsoen van de bezochte melkveebedrijven.

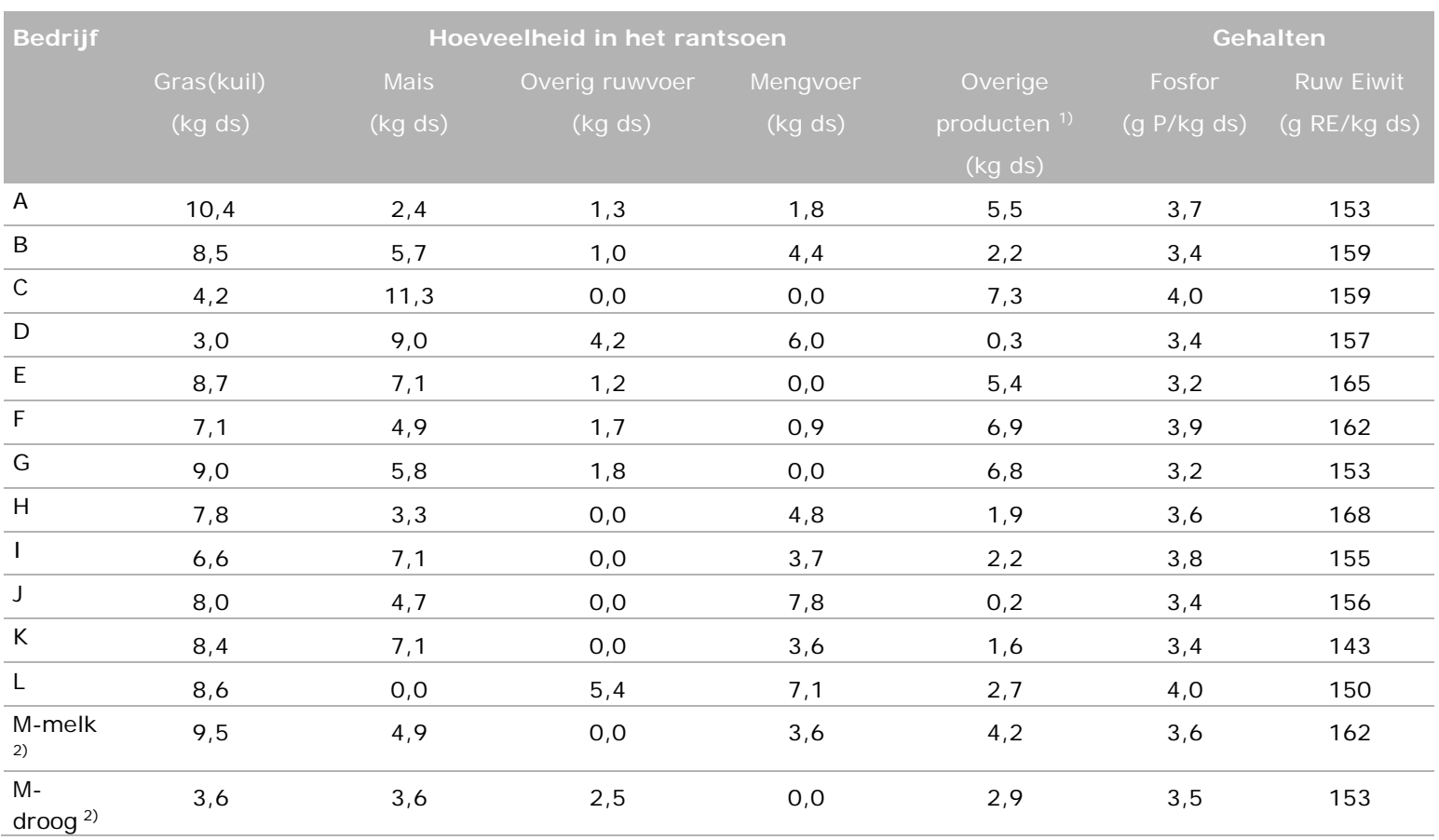

1) Overige producten die bepaalde bedrijven voeren waren tarwegistconcentraten, enkelvoudige grondstoffen, mineralen en additieven.

2) Op bedrijf M zijn monsters genomen van de mestrobot bij de melkgevende en droge koeien.

Op de bedrijven werden verschillende mestscheiders gebruikt voor het scheiden van de mest. Per type mestscheider zijn twee of drie melkveebedrijven bezocht. Op de bedrijven zijn van de drijfmest, de dikke en dunne fractie mestmonsters genomen. Op twee melkveebedrijven met een stalreinigingsrobot en één bedrijf met een mestschuif zijn mestmonsters genomen van de faeces. $\mathrm{Er}$ zijn geen monsters genomen van de urine, omdat de urine van melkkoeien zo goed als geen fosfaat 
bevat (Goselink et al., 2015). In tabel 2 staan de gebruikte mestscheiders of uitmestsystemen die in het onderzoek op de bezochte melkveebedrijven zijn gebruikt.

Tabel 2 Toegepaste mestscheider of mestrobot ten tijde van het onderzoek.

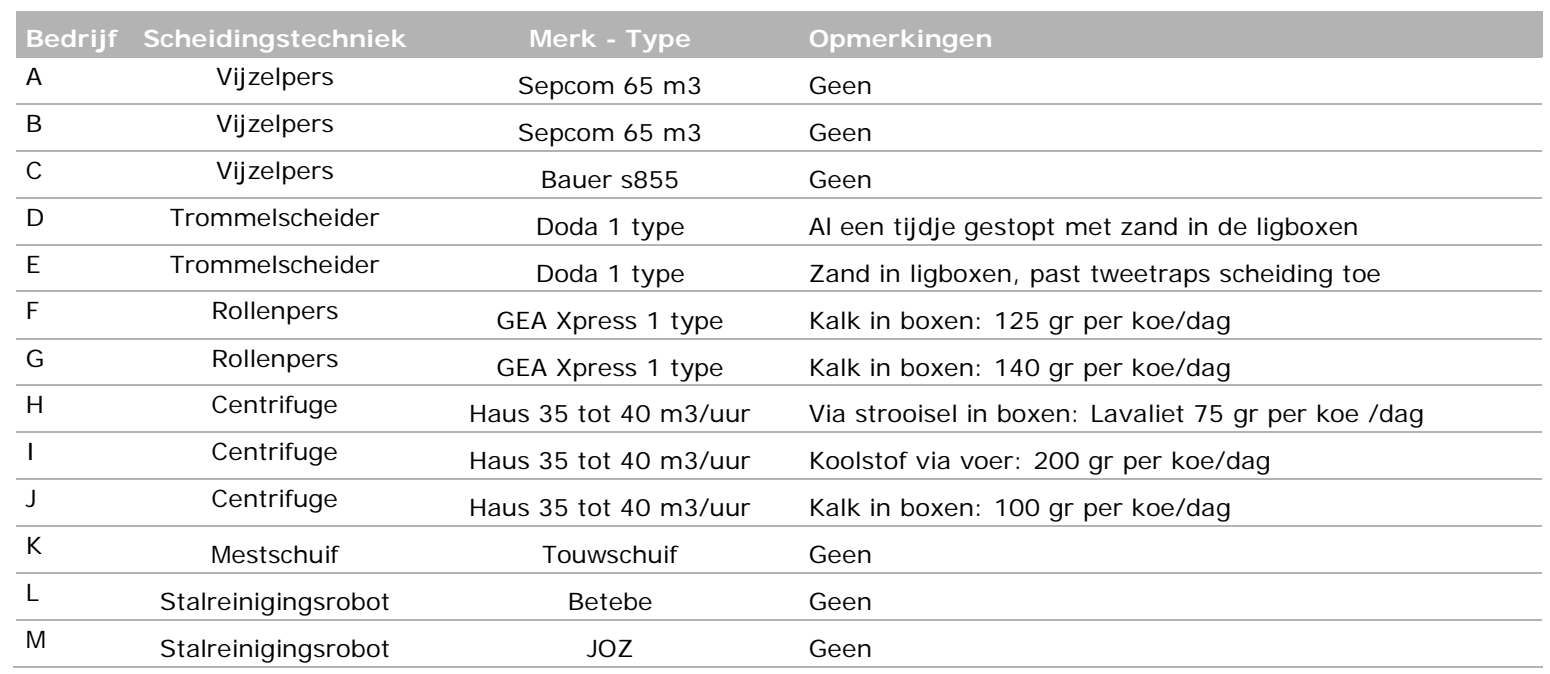

\subsection{Monsternamemethode}

Tijdens het scheiden van de mest heeft de monstername plaatsgevonden. Om zo representatief mogelijke monsters te nemen, werd de ingaande drijfmest naar de mestscheiders - voor zover dat mogelijk was - eerst gemengd en bij de tappunten werd eerst wat vloeistof afgelaten voordat de monsters werden genomen. Van de drijfmest, dunne en dikke fractie zijn met een tussenpauze van circa 15 minuten drie deelmonsters van circa 1,7 liter genomen tijdens het scheidingsproces, zodat in totaal ongeveer vijf liter werd verzameld. Deze drie deelmonsters werden vervolgens goed met elkaar gemengd tot een mengmonster van 5 liter. Van de drijfmest en dikke fractie werden uit het mengmonster twee monsters genomen van 1 liter en bewaard in luchtdichte monsterflessen. De vijf liter dunne fractie werd in zijn geheel in een luchtdichte emmer gedaan. Bij de stalreinigingsrobots zijn van de faeces met een tussenpauze van 15 minuten ook drie deelmonsters van circa 1,7 liter genomen tijdens het normale bedrijfsgebruik, zodat in totaal 5 liter werd verzameld wat goed met elkaar vermengd werd tot een mengmonster waaruit vervolgens twee monsters van 1 liter werd genomen. Alle monsters zijn na monstername zo snel als mogelijk in de koeling gezet en daarna in een vriescel bewaard tot aan analyse in het laboratorium.

\subsection{Analysemethoden}

\subsubsection{Mestanalyses}

De drijfmest, dunne en dikke fractie en faeces zijn in het laboratorium van Wageningen Livestock Research geanalyseerd op de volgende parameters:
- $\quad$ Droge stof gehalte (drogen bij $105 \stackrel{\circ}{\circ}$ ) (NEN 7432)
- $\quad$ Organische stof (o.b.v. gloeiverlies) (NEN 7432)
- Totaal-N (NEN 7434)
- Totaal-P uitgedrukt als $\mathrm{P}_{2} \mathrm{O}_{5}$ (NEN 7435)
- $\quad$ Orthofosfaat (NEN 6479)
- $\quad$ Calcium (ICP-bepaling na destructie met $\mathrm{HCL} / \mathrm{HNO}_{3}$ )
- $\quad$ Magnesium (ICP-bepaling na destructie met $\mathrm{HCL} / \mathrm{HNO}_{3}$ )

De analyseresultaten zijn uitgedrukt in gram per kilogram product tenzij anders aangegeven. Waar fosfor staat geschreven betekent dat dit uitgedrukt is in P en waar fosfaat staat betekent dat het uitgedrukt is in $\mathrm{P}_{2} \mathrm{O}_{5}$. Het orthofosfaat gehalte was in de dikke fractie niet zonder verdunning te bepalen. Als schatting is aangenomen dat het orthofosfaat gehalte in de waterfase van de dikke fractie gelijk is aan het gehalte in de waterfase van de dunne fractie. 


\subsubsection{Analyse van fosfaatvormen in dunne fractie van mest}

Om het winningspotentieel in beeld te brengen is allereerst inzicht nodig in de fosfaatvormen in dunne fractie van mest. Binnen dit onderzoek zijn drie groepen onderscheiden:

- Orthofosfaat (i.e. het daadwerkelijk opgeloste orthofosfaat $\left(\mathrm{PO}_{4}{ }^{3-}, \mathrm{HPO}_{4}{ }^{2-}\right.$, etc.),

- Mineraal fosfaat (o.a. calciumfosfaat, struviet),

- Organisch fosfaat (o.a. fytaat, celwanden, fosfolipiden, etc.).

Vanwege het ontbreken van een standaard protocol voor het analyseren van orthofosfaat in mestmonsters is een vergelijkende studie uitgevoerd waarbij orthofosfaat is bepaald volgens drie verschillende methoden uitgevoerd door twee verschillende laboratoria. Om orthofosfaat in mestmonsters te kunnen meten is het noodzakelijk om de waterfase van de monsters af te scheiden, omdat de aanwezigheid van fosfaat colloïden een overschatting geeft van de orthofosfaat concentratie (Moorleghem et al., 2011). Hiervoor zijn drie methoden voorgesteld waarbij de waterfase van de dunne fractie wordt afgescheiden door herhaaldelijk centrifugeren (analysemethode 1 ) of een combinatie met centrifugeren, verdunnen en filtreren (analysemethode 2 en 3). Omdat onbekend is in hoeverre deze voorbehandelingen effect hebben op de gemeten orthofosfaat concentratie zijn de volgende drie methoden getest:

\section{Analysemethode 1}

1. De dunne fractie werd eerst gecentrifugeerd bij $4.500 \mathrm{rpm}$.

2. Het supernatant uit stap 1 werd vervolgens gecentrifugeerd bij $14.000 \mathrm{rpm}$.

3. Supernatant uit stap 2 werd $10 x$ verdund zo kort mogelijk voor de bepaling van het orthofosfaatgehalte.

4. Verdunde supernatant centrifugeren bij 14.000 rpm. Monsters werden niet gefiltreerd.

5. Vervolgens werd het fosfaat bepaald zonder destructie m.b.v. een kleuringsreactie welke specifiek is voor orthofosfaat.

\section{Analysemethode 2}

1. 1 gram dunne fractie werd gemengd met 29 gram demiwater en direct daarna gecentrifugeerd op $10.000 \mathrm{rpm}$.

2. Supernatant werd afgegoten en gefiltreerd over $0.45 \mu \mathrm{m}$ membraanfilters. Het filtreren van het supernatant verliep moeizaam door de aanwezigheid van colloïden. Na filtratie zijn de monsters twee maal verdund voor analyse.

3. Analyse van het filtraat orthofosfaat m.b.v. een kleuringsreactie zonder destructie.

4. De resultaten zijn weergegeven onder twee aannames;

- 2a: De gemeten orthofosfaat concentratie uitgedrukt per kg ingewogen dunne fractie (i.e. gemeten concentratie maal factor 30). Dit is geldig onder de aanname dat er géén extractie van orthofosfaat vanuit de vaste fase plaats vindt.

o 2b: De daadwerkelijk gemeten concentraties in het filtraat. Er wordt aangenomen dat het chemisch evenwicht tussen de fosfaatmineralen en de orthofosfaat concentratie niet verander door de additie van water.

\section{Analysemethode 3}

1. Dunne fractie centrifugeren bij $10.000 \mathrm{rpm}$.

2. Supernatant afscheiden en daarna $10 x$ verdunnen met demiwater en direct filtreren over 0.45 $\mu \mathrm{m}$.

3. Analyse van het filtraat orthofosfaat m.b.v. een kleuringsreactie zonder destructie.

Analysemethode 1 is uitgevoerd door het laboratorium van Wageningen Livestock Research terwijl methode 2 en 3 zijn uitgevoerd door het Chemisch Biologisch Laboratorium Bodem (CBLB) onderdeel van de Wageningen Universiteit.

\section{Mineraal en organisch fosfaat}

Het aandeel mineraal fosfaat is bepaald door extractie van 4 gram mest met $36 \mathrm{~mL} 0.5 \mathrm{M} \mathrm{H}_{2} \mathrm{SO}_{4}$ gevolgd door analyse van het filtraat op orthofosfaat door middel van een kleuringsmethode met correctie voor de reeds aanwezige orthofosfaat. Met deze methode wordt aangenomen dat fosfaatmineralen zoals calciumfosfaat, volledig in oplossing gaan. Het totale fosfaat gehalte 
(orthofosfaat + mineraal + organisch) in de dunne fractie is bepaald na destructie met aqua regia behulp van een magnetron methode. Het aandeel organisch fosfaat is gedefinieerd als het verschil tussen orthofosfaat plus mineraal fosfaat en totaal fosfaat. De analyses zijn uitgevoerd door het Chemisch Biologisch Laboratorium Bodem (CBLB) onderdeel van de Wageningen Universiteit.

\subsubsection{Terugwinning van fosfaat uit de dunne fractie}

In aanvulling op de bepaling van het gehalte aan orthofosfaat in de dunne fractie is getracht het orthofosfaat uit de dunne fractie te winnen door dosering van calciumhydroxide $\left(\mathrm{Ca}(\mathrm{OH})_{2}\right)$. Deze methode is gebaseerd op het principe dat calcium met orthofosfaat neerslaat in de vorm van calciumfosfaat mineralen welke afgescheiden kunnen worden van de vloeistof. Het perspectief van deze methode is vooralsnog onbekend en hangt o.a. samen met het orthofosfaat gehalte in de dunne fractie. Daarnaast kan een deel van het fosfaat aanwezig zijn in de vorm van minerale colloïden (calciumfosfaat) en organische colloïden (o.a. fytaat). Het is onbekend in hoeverre colloïdale fosfaatvormen door middel van calciumhydroxide dosering teruggewonnen kunnen worden uit de dunne fractie. Vanwege de lage gehalten aan orthofosfaat in de dunne fracties is alleen calciumhydroxide toegevoegd aan de dunne fracties met de hoogste orthofosfaat concentratie per mestscheider en dat betroffen de dunne fracties afkomstig van de volgende bedrijven:

- $\quad$ Bedrijf A: vijzelpers

- Bedrijf D: trommelscheider

- Bedrijf F: rollenpers

- Bedrijf H: centrifuge

's Ochtends werd in een bekerglas van $800 \mathrm{ml}$ een hoeveelheid van 500 à $600 \mathrm{ml}$ dunne fractie gedaan. Aan de dunne fracties werd een overmaat calciumhydroxide ( $2 x$ zoveel op mol-basis als orthofosfaat) toegevoegd om de orthofosfaat te laten neerslaan. Vervolgens werd het mengsel circa 1 uur geroerd m.b.v. een magneetroerder. Elk 30 à 60 minuten werd visueel de mate van bezinking gecontroleerd en indien mogelijk een streepje op het bekerglas gezet wat de hoogte van het bezinksel was. Afhankelijk van de mate van bezinking werd de proef aan het eind van de dag beëindigd of de volgende ochtend. Na bezinking werd het supernatant gescheiden van het sediment d.m.v. centrifugeren. De ingaande dunne fractie, het centrifugaat en sediment zijn gewogen en geanalyseerd op: drogestof, fosfaat, orthofosfaat en $\mathrm{pH}$. Bij de uitvoering is geen controle behandeling meegenomen zonder calciumhydroxide dosering.

\subsubsection{Terugwinning van fosfaat uit de dikke fractie}

Circa 200 gram dikke fractie is met water verdund tot een mengsel met circa $6 \%$ drogestof en daarna met één molair zwavelzuur aangezuurd tot pH 6 en pH 5. Bij beide pH-waarden en de initiële pH is een submonster genomen waarvan de waterfase is afgescheiden door centrifugeren en filtreren. Het filtraat is geanalyseerd op orthofosfaat, totaal fosfaat, calcium en magnesium. De analyse is niet uitgevoerd voor mest van bedrijven $A, B$ en $E$. 


\section{Resultaten}

\subsection{Vergelijking analysemethoden orthofosfaat}

In tabel 3 staat de vergelijking tussen de analyseresultaten van analysemethoden $1,2 \mathrm{a}, 2 \mathrm{~b}$ en 3 voor de bepaling van het orthofosfaat gehalte in de dunne fracties.

Tabel 3 Vergelijking van het resultaat van verschillende analysemethoden (AM1 t/m AM3) voor de bepaling van het orthofosfaat gehalte in de dunne fracties alsmede de verhouding orthofosfaat/totaal fosfaat.

\begin{tabular}{|c|c|c|c|c|c|c|c|c|}
\hline \multirow[b]{2}{*}{ Bedrijf } & \multicolumn{4}{|c|}{ Ortho- $\mathrm{P}_{2} \mathrm{O}_{5}(\mathrm{mg} / \mathrm{L})$} & \multicolumn{4}{|c|}{$\begin{array}{l}\text { Ortho- } \mathrm{P}_{2} \mathrm{O}_{5} / \text { totaal- } \mathrm{P}_{2} \mathrm{O}_{5} \\
\qquad(\%)\end{array}$} \\
\hline & AM1 & AM2a & AM2b & $A M 3$ & AM1 & AM2a & AM2b & AM3 \\
\hline A & 22 & 593 & 20 & 30 & $1 \%$ & $36 \%$ & $1 \%$ & $2 \%$ \\
\hline B & 20 & 366 & 12 & 22 & $2 \%$ & $26 \%$ & $1 \%$ & $2 \%$ \\
\hline C & 5 & 891 & 30 & 61 & $0 \%$ & $47 \%$ & $2 \%$ & $3 \%$ \\
\hline $\mathrm{D}$ & 30 & 550 & 18 & 25 & $3 \%$ & $43 \%$ & $2 \%$ & $2 \%$ \\
\hline$E$ & 6 & 742 & 25 & 59 & $0 \%$ & $29 \%$ & $1 \%$ & $3 \%$ \\
\hline $\mathrm{F}$ & 1 & 564 & 19 & 63 & $0 \%$ & $48 \%$ & $2 \%$ & $5 \%$ \\
\hline G & 4 & 497 & 17 & 76 & $0 \%$ & $39 \%$ & $2 \%$ & $7 \%$ \\
\hline $\mathrm{H}$ & 23 & 257 & 9 & 0 & $4 \%$ & $37 \%$ & $1 \%$ & $0 \%$ \\
\hline I & 0 & 129 & 4 & 22 & $0 \%$ & $46 \%$ & $2 \%$ & $4 \%$ \\
\hline J & 3 & 368 & 12 & 23 & $0 \%$ & $38 \%$ & $2 \%$ & $9 \%$ \\
\hline
\end{tabular}

Er blijken grote verschillen te zijn tussen de resultaten van de verschillende analysemethoden. Bij analysemethode 1, waarbij de waterfase door herhaaldelijk centrifugeren wordt afgescheiden, liggen de orthofosfaat gehalten tussen de 0 en $30 \mathrm{mg} / \mathrm{l}$. Het eerst verdunnen van de mest met water gevolgd door centrifugeren en filtreren geeft orthofosfaat gehalten van 129 tot $891 \mathrm{mg} / \mathrm{l}$ (analysemethode $2 \mathrm{a}$ ). Hierbij is de orthofosfaat concentratie in het filtraat teruggerekend naar de ingewogen hoeveelheid mest zoals gebruikelijk is bij de uitvoering van extracties (i.e. maal de verdunningsfactor). Indien de gemeten waarden in het filtraat worden gerapporteerd (analysemethode $2 \mathrm{~b}$ ) zijn de resultaten wel vergelijkbaar met methode 1 met gehalten tussen 4 en $30 \mathrm{mg} / \mathrm{l}$. De verklaring hiervoor is dat de orthofosfaat concentratie in evenwicht is met calciumfosfaatmineralen in de mest. Dit evenwicht blijft ook na verdunning gehandhaafd. Daarnaast is analysemethode 3 uitgevoerd waarbij de mest is gecentrifugeerd en waarna het supernatant is verdund en gefiltreerd. Deze methode geeft in ordegrootte vergelijkbare resultaten als methode 1 en $2 \mathrm{~b}$, met gehalten tussen de 0 en $76 \mathrm{mg} / \mathrm{l}$.

De analyseresultaten van het orthofosfaat gehalte in de drijfmest, dunne en dikke fractie en faeces zijn op basis van analysemethode 1 in deze rapportage opgenomen. 


\subsection{Samenstelling drijfmest}

In tabel 4 staat de samenstelling van de onderzochte drijfmesten weergegeven.

Tabel 4 Analyseresultaten van de ingaande drijfmest naar de mestscheiders per kg product.

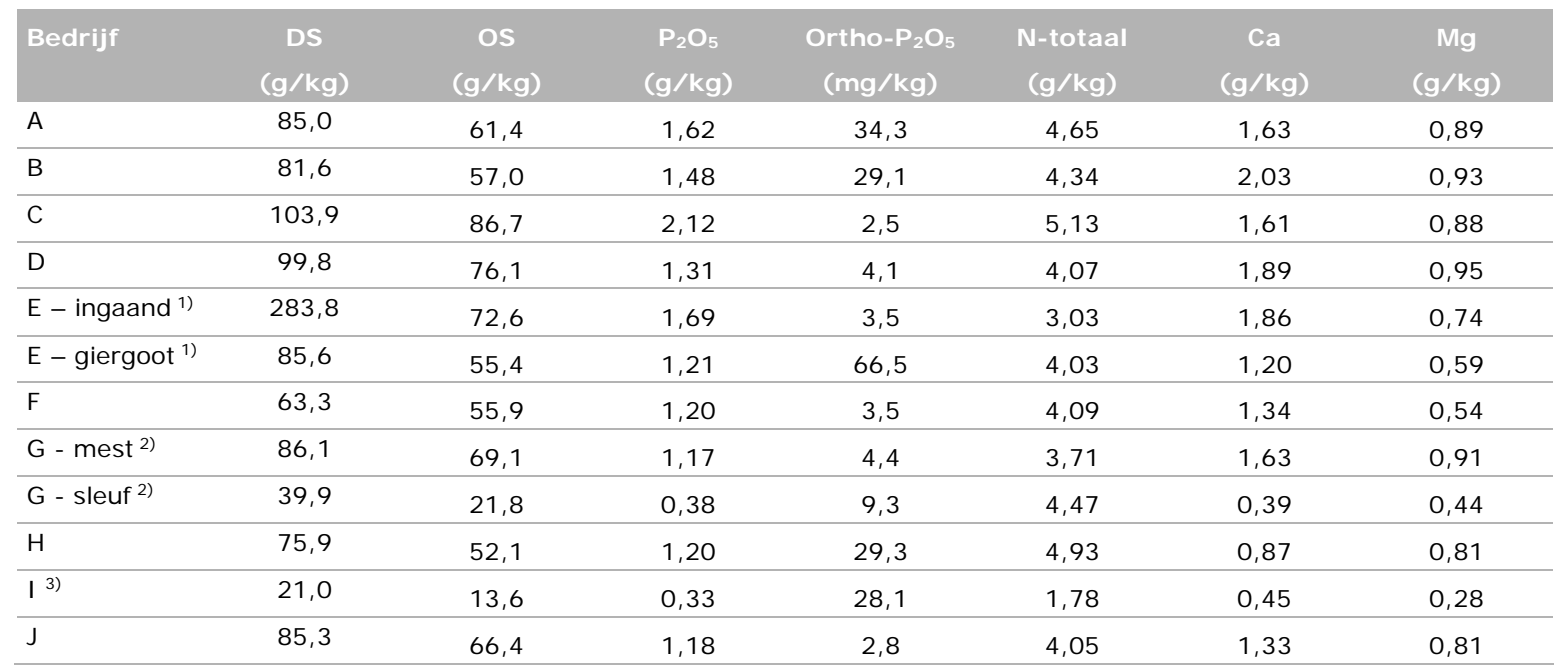

1) Bedrijf met een hellende vloer en giergoot. Vóór de afstort van de dikkere mest zit een smalle afstort voor de gier. Tijdens schuiven loopt vóór de schuif een plas dunne fractie, die door de gier afstort valt. De dikkere mest gaat er overheen en komt in de grote bezinkput (nodig vanwege het gebruik van zand in de boxen) en gaat vanuit de bezinkput naar de mestscheider.

2) Op dit bedrijf is de drijfmest afkomstig van een sleuvenvloer. De sleuf-fractie is de fractie die door de sleuvenvloer heen werd opgevangen.

3) Het zeer lage drogestof op dit melkveebedrijf werd veroorzaakt door spoelwater en erfwater wat bij de mest terecht kwam.

De tabel laat de volgende variatie in gehalten zien in de drijfmest: fosfaat van 0,33 tot $2,12 \mathrm{~g} / \mathrm{kg}$, orthofosfaat van 2,8 tot $66,5 \mathrm{mg} / \mathrm{kg}$, aandeel van orthofosfaat t.o.v. totaal fosfaat van vrijwel 0 tot $8 \%$, stikstof van 1,78 tot $5,13 \mathrm{~g} / \mathrm{kg}$, calcium van 0,45 tot $2,03 \mathrm{~g} / \mathrm{kg}$ en magnesium van 0,28 tot 0,95 $\mathrm{g} / \mathrm{kg}$.

In figuren 1a t/m c staan de belangrijkste relaties m.b.t. fosfaat, orthofosfaat, calcium en magnesium in de drijfmest weergegeven met indicatieve trendlijnen. Hierbij zijn de bedrijven $\mathrm{E}$ en $\mathrm{G}$ buiten beschouwing gelaten, omdat op deze bedrijven reeds een voorscheiding had plaatsgevonden. Er blijkt geen relatie gelegd te kunnen worden tussen het orthofosfaat gehalte in de mest en het fosfaatgehalte in de mest op zowel product als op droge stof basis, omdat de spreiding in het orthofosfaat gehalte te groot is. Tussen het fosfaatgehalte en het calcium- en magnesiumgehalte lijkt er wel een verband te zijn. Hoe hoger het calcium- en magnesiumgehalte in de drijfmest hoe hoger het fosfaatgehalte is. Dit verband gaat niet op voor het orthofosfaat gehalte in de drijfmest in relatie tot het calcium- en magnesiumgehalte in de drijfmest, omdat de spreiding in het orthofosfaat gehalte te groot is. 

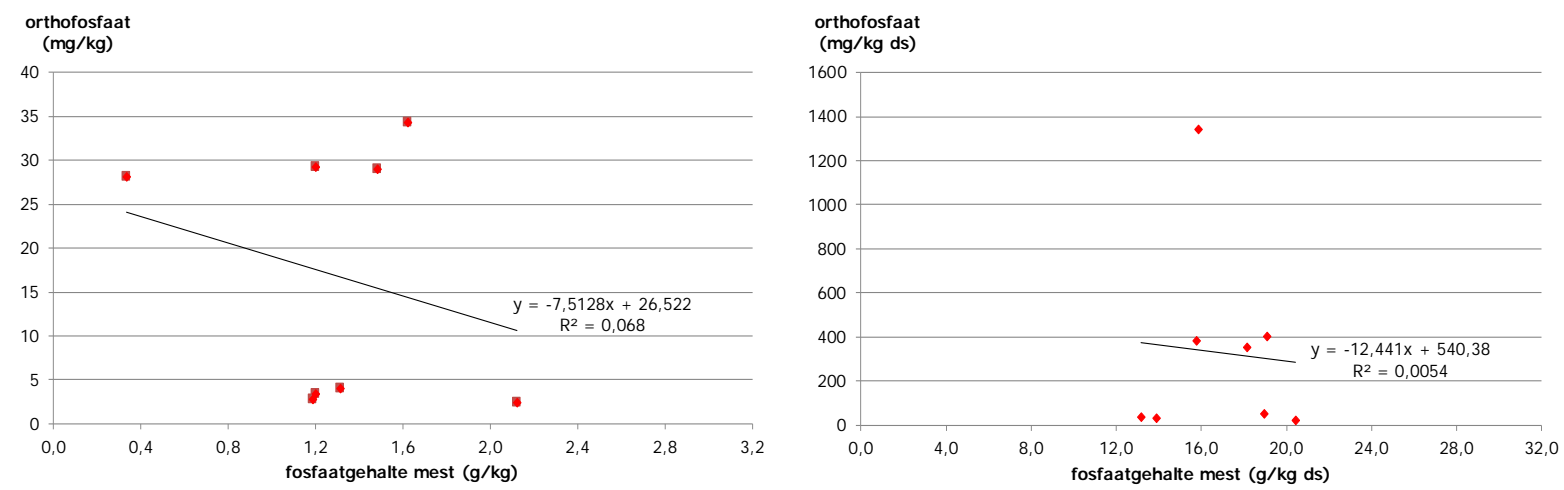

Figuur 1a Het orthofosfaat gehalte in de drijfmest in relatie tot het fosfaatgehalte in de drijfmest op product en droge stof basis.
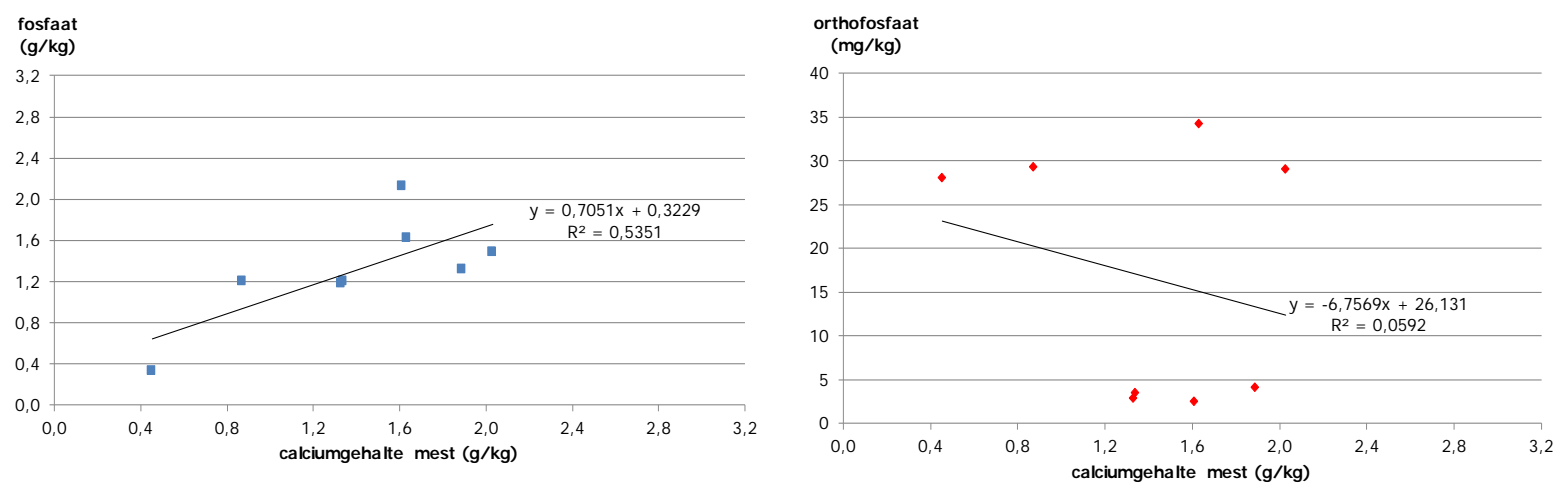

Figuur 1b Het fosfaat en orthofosfaat gehalte in de drijfmest in relatie tot het calciumgehalte in de drijfmest.
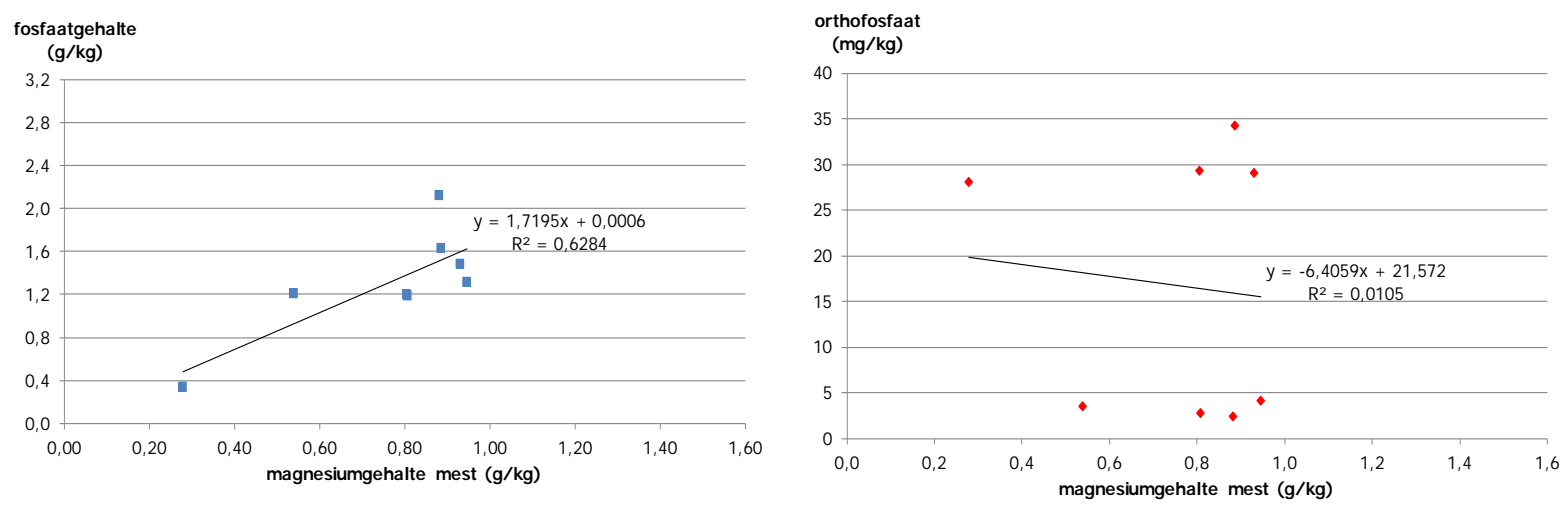

Figuur 1c Het fosfaat en orthofosfaat gehalte in de drijfmest in relatie tot het magnesiumgehalte in de drijfmest. 


\subsection{Samenstelling dunne fractie}

In tabel 5 staan de analyseresultaten van de dunne fracties afkomstig van de mestscheiders weergegeven.

Tabel 5 Analyseresultaten van de dunne fracties uit de mestscheiders per kg product.

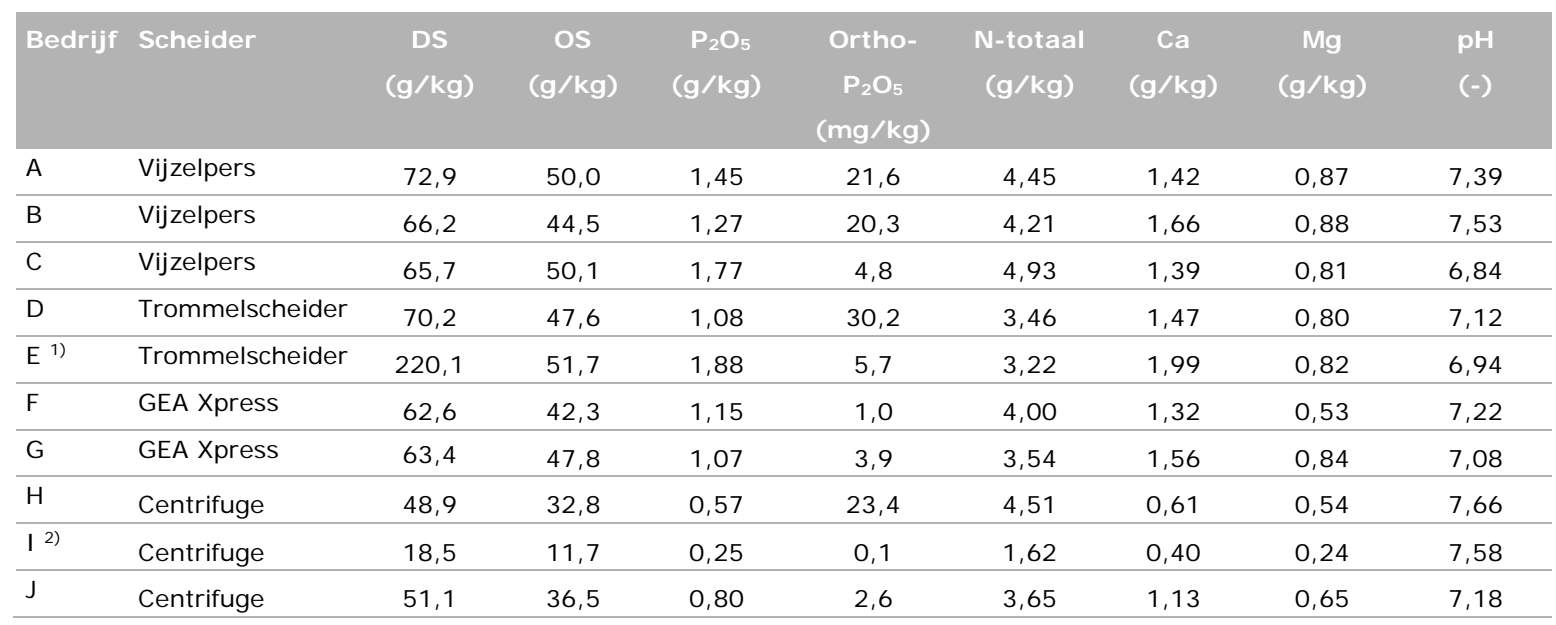

1) Op dit bedrijf werd zand in de boxen gebruikt wat leidde tot een groot aandeel zand in de dunne fractie en daarmee een hoog drogestofgehalte.

2) Het zeer lage drogestof op dit melkveebedrijf werd veroorzaakt door spoelwater en erfwater wat bij de mest terecht kwam.

De tabel laat de volgende variatie in gehalten zien in de dunne fracties: fosfaat van 0,25 tot 1,88 $\mathrm{g} / \mathrm{kg}$, orthofosfaat van 0,1 tot $30,2 \mathrm{mg} / \mathrm{kg}$, aandeel van orthofosfaat t.o.v. totaal fosfaat van 0 tot $4 \%$, stikstof van 1,62 tot $4,93 \mathrm{~g} / \mathrm{kg}$, calcium van 0,40 tot $1,99 \mathrm{~g} / \mathrm{kg}$, magnesium van 0,24 tot $0,88 \mathrm{~g} / \mathrm{kg}$ en de $\mathrm{pH}$ van 6,8 en 7,6 .

In figuren $2 \mathrm{a} \mathrm{t} / \mathrm{m}$ d staan de belangrijkste relaties m.b.t. fosfaat, orthofosfaat, calcium en magnesium in de dunne fractie weergegeven met indicatieve trendlijnen. Hierbij is bedrijf $E$ buiten beschouwing gelaten vanwege het hoge aandeel zand in de dunne fractie. Er blijkt een verband te zijn tussen het fosfaatgehalte in de dunne fractie en het fosfaatgehalte in de ingaande mest. Wat opvalt is dat de bedrijven met een vijzelpers hogere fosfaatgehalten in de mest hebben dan de andere bedrijven. Er blijkt geen relatie gelegd te kunnen worden tussen het orthofosfaat gehalte in de dunne fractie en het fosfaatgehalte in de ingaande mest en dunne fractie. De spreiding in het orthofosfaat gehalte is te groot om verbanden te kunnen leggen met het fosfaatgehalte. Tussen het fosfaatgehalte en het calcium- en magnesiumgehalte lijkt er wel een verband te zijn. Hoe hoger het calcium- en magnesiumgehalte hoe hoger het fosfaatgehalte in de dunne fractie. Dit verband gaat niet op voor het orthofosfaat gehalte in relatie tot het calcium- en magnesiumgehalte in de dunne fractie, omdat de spreiding in het orthofosfaat gehalte te groot is. 


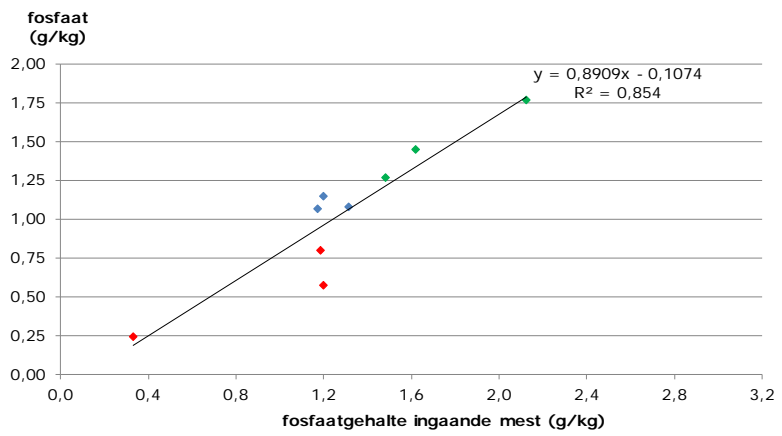

Figuur 2a Fosfaatgehalte in de dunne fractie in relatie tot het fosfaatgehalte in de ingaande mest (groen $=$ vijzelpers; blauw $=$ trommelscheider/rollenpers; rood $=$ centrifuge)
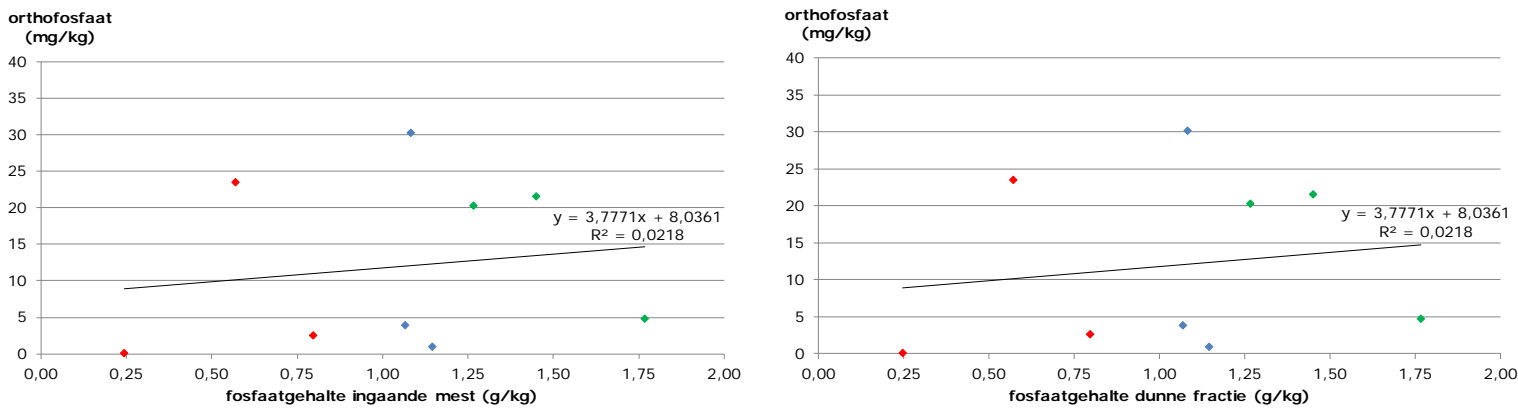

Figuur $\mathbf{2 b}$ Het orthofosfaat gehalte in de dunne fractie in relatie tot het fosfaatgehalte in de ingaande mest (links) en het fosfaatgehalte in de dunne fractie (rechts) (groen = vijzelpers; blauw = trommelscheider/rollenpers; rood = centrifuge).
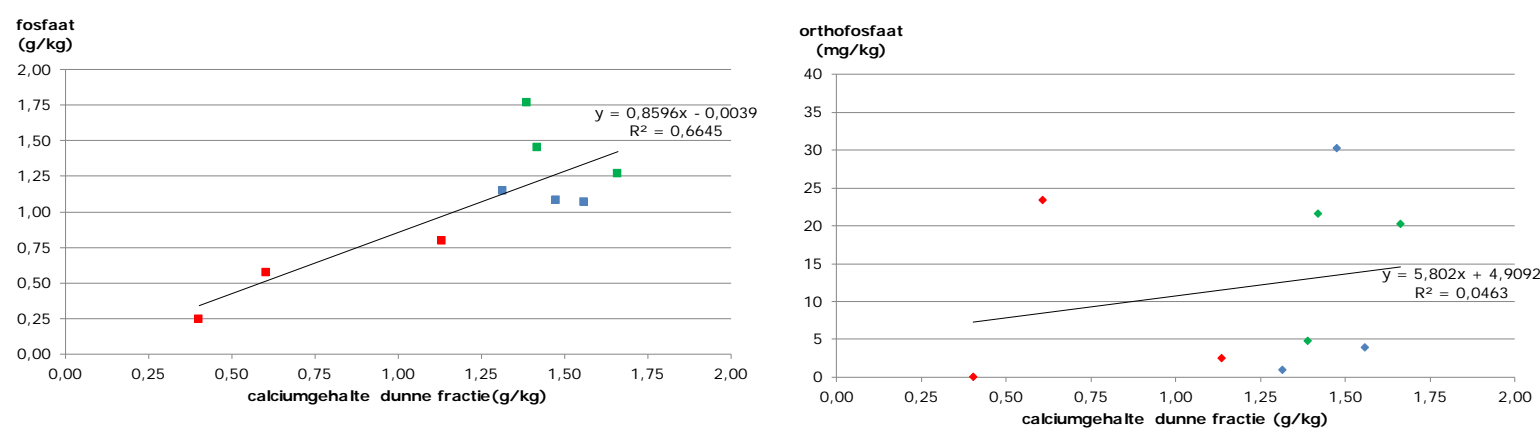

Figuur 2c Het fosfaat en orthofosfaat gehalte in de dunne fractie in relatie tot het calciumgehalte in de dunne fractie (groen = vijzelpers; blauw = trommelscheider/rollenpers; rood = centrifuge).
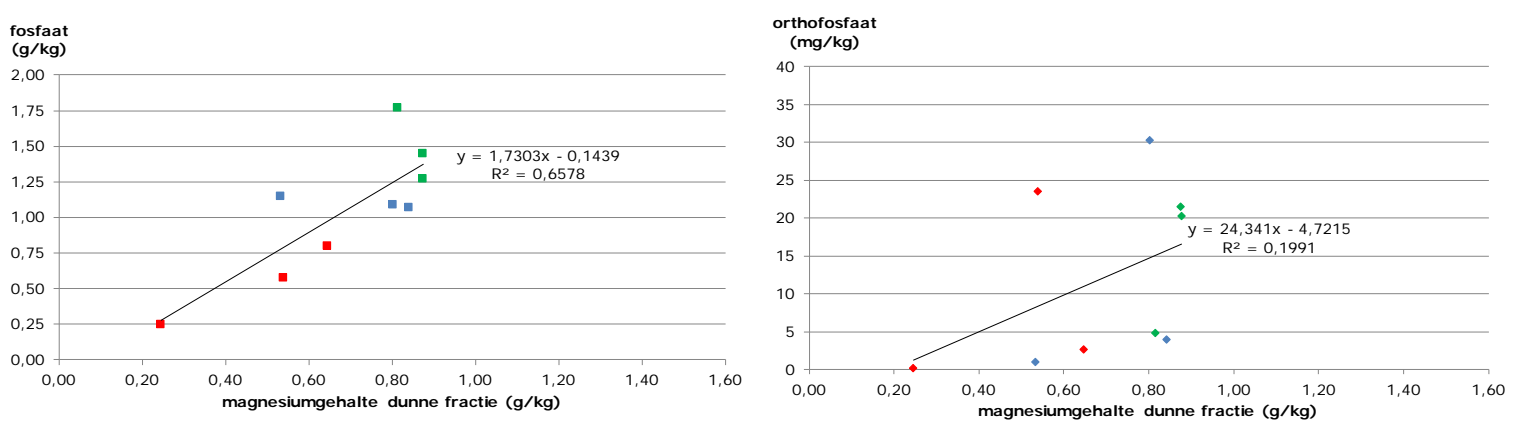

Figuur 2d Het fosfaat en orthofosfaat gehalte in de dunne fractie in relatie tot het magnesiumgehalte in de dunne fractie (groen = vijzelpers; blauw = trommelscheider/rollenpers; rood = centrifuge). 
In figuur 3 staan het aandeel orthofosfaat, mineraal fosfaat en organisch fosfaat t. o.v. totaal fosfaat in de dunne fracties weergegeven. Het aandeel orthofosfaat varieerde van 0 tot $4 \%$. Het mineraal fosfaat (i.e. anorganisch fosfaat, extraheerbaar met zwavelzuur) vormde het grootste aandeel met 43 tot $81 \%$ van de totale hoeveelheid fosfaat in de dunne fractie. Het organisch fosfaat varieerde van 18 tot $53 \%$ van de totale hoeveelheid fosfaat in de dunne fractie. Het overgrote deel van het fosfaat in de dunne fractie blijkt aanwezig te zijn in de vorm van mineraal fosfaat, i.e. calciumfosfaat en magnesiumfosfaat

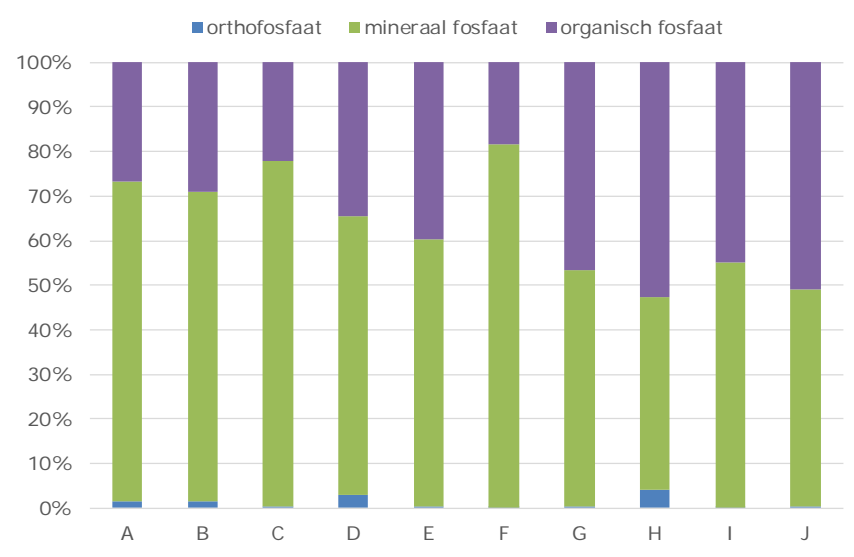

Figuur 3 Het orthofosfaat, mineraal fosfaat en de organisch fosfaat als aandeel in de totale fosfaat in de dunne fracties.

In figuur 3 staan het aandeel orthofosfaat, mineraal fosfaat en organisch fosfaat t.o.v. totaal fosfaat in de dunne fracties weergegeven. Het aandeel orthofosfaat varieerde van 0 tot $4 \%$. Het mineraal fosfaat (i.e. anorganisch fosfaat, extraheerbaar met zwavelzuur) vormde het grootste aandeel met 43 tot $81 \%$ van de totale hoeveelheid fosfaat in de dunne fractie. Het organisch fosfaat varieerde van 18 tot $53 \%$ van de totale hoeveelheid fosfaat in de dunne fractie. Het overgrote deel van het fosfaat in de dunne fractie blijkt aanwezig te zijn in de vorm van mineraal fosfaat, i.e. calciumfosfaat en magnesiumfosfaat 


\subsection{Samenstelling dikke fractie}

In tabel 6 staan de analyseresultaten van de dikke fracties afkomstig van de mestscheiders weergegeven.

Tabel 6 Analyseresultaten van de dikke fracties uit de mestscheiders per kg product.

\begin{tabular}{|c|c|c|c|c|c|c|c|c|}
\hline Bedrijf & Scheider & $\begin{array}{c}\text { DS } \\
(\mathrm{g} / \mathrm{kg})\end{array}$ & $\begin{array}{c}\text { os } \\
(\mathrm{g} / \mathrm{kg})\end{array}$ & $\begin{array}{c}\mathrm{P}_{2} \mathrm{O}_{5} \\
(\mathrm{~g} / \mathrm{kg})\end{array}$ & $\begin{array}{c}\text { Ortho- } \mathrm{P}_{2} \mathrm{O}_{5}{ }^{3)} \\
\text { ( } \mathrm{mg} / \mathrm{kg})\end{array}$ & $\begin{array}{c}N \\
(g / k g)\end{array}$ & $\begin{array}{c}\mathrm{Ca} \\
(\mathrm{g} / \mathrm{kg})\end{array}$ & $\begin{array}{c}M g \\
(g / k g)\end{array}$ \\
\hline A & Vijzelpers & 316 & 277 & 3,03 & 15,9 & 6,48 & 3,78 & 1,52 \\
\hline C & Vijzelpers & 261 & 239 & 3,05 & 3,8 & 5,48 & 2,14 & 1,16 \\
\hline $\mathrm{D}$ & Trommelscheider & 254 & 188 & 1,63 & 24,2 & 4,46 & 2,62 & 1,05 \\
\hline $\mathrm{F}$ & GEA Xpress & 281 & 245 & 2,81 & 0,7 & 5,51 & 2,87 & 1,25 \\
\hline G & GEA Xpress & 222 & 198 & 1,21 & 3,2 & 4,22 & 2,39 & 1,17 \\
\hline $\mathrm{H}$ & Centrifuge & 209 & 153 & 4,00 & 19,5 & 5,82 & 2,62 & 2,30 \\
\hline I 2) & Centrifuge & 144 & 112 & 4,29 & 0,1 & 4,36 & 1,83 & 1,78 \\
\hline
\end{tabular}

1) Op dit bedrijf werd gebruikt van zand in de boxen wat leidde tot een groot aandeel zand in de dikke fractie en daarmee een hoog drogestofgehalte.

2) Het zeer lage drogestof op dit melkveebedrijf werd veroorzaakt door spoelwater en erfwater wat bij de mest terecht kwam.

3) Het orthofosfaat gehalte was in de dikke fractie niet zonder verdunning te bepalen. Als schatting is aangenomen dat het orthofosfaat gehalte in de waterfase van de dikke fractie gelijk is aan het gehalte in de waterfase van de dunne fractie.

De tabel laat de volgende variatie in gehalten zien in de dikke fracties: fosfaat van 1,21 tot 4,29 g/ $\mathrm{kg}$, berekende orthofosfaat van 0,1 tot $24,2 \mathrm{mg} / \mathrm{kg}$, aandeel van orthofosfaat t.o.v. totaal fosfaat van 0 tot $1,5 \%$, stikstof van 2,89 tot $6,48 \mathrm{~g} / \mathrm{kg}$, calcium van 1,83 tot $6,12 \mathrm{~g} / \mathrm{kg}$ en magnesium van 0,73 tot $2,41 \mathrm{~g} / \mathrm{kg}$.

In figuren $4 \mathrm{a}$ t/m d staan de belangrijkste relaties m.b.t. fosfaat, orthofosfaat, calcium en magnesium in de dikke fractie weergegeven met indicatieve trendlijnen. Hierbij is bedrijf $E$ buiten beschouwing gelaten vanwege het hoge aandeel zand in de dikke fractie. Er blijkt geen duidelijk verband te zijn tussen het fosfaatgehalte in de dikke fractie en het fosfaatgehalte in de ingaande mest. Er blijkt geen relatie gelegd te kunnen worden tussen het orthofosfaat gehalte in de dikke fractie en het fosfaatgehalte in de ingaande mest en de dikke fractie. De spreiding in het orthofosfaat gehalte is te groot om verbanden te kunnen leggen met het fosfaatgehalte. Tussen zowel het fosfaat als het orthofosfaat gehalte en het calciumgehalte blijkt er geen verband te zijn. Echter tussen het fosfaatgehalte en het magnesiumgehalte lijkt er wel een verband te zijn. Hoe hoger het magnesiumgehalte hoe hoger het fosfaatgehalte in de dikke fractie. Dit verband gaat niet op voor het orthofosfaat gehalte in relatie tot het magnesiumgehalte in de dikke fractie, omdat de spreiding in het orthofosfaat gehalte te groot is. 


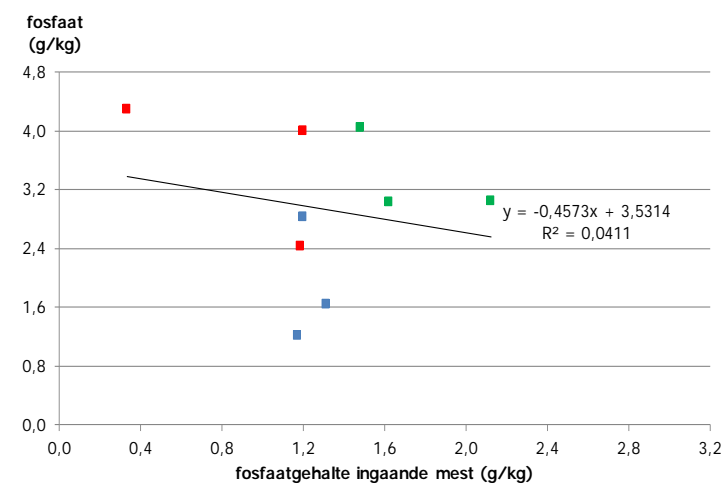

Figuur 4a Fosfaatgehalte in de dikke fractie in relatie tot het fosfaatgehalte in de ingaande mest ( groen $=$ vijzelpers; blauw $=$ trommelscheider/rollenpers; rood $=$ centrifuge) .
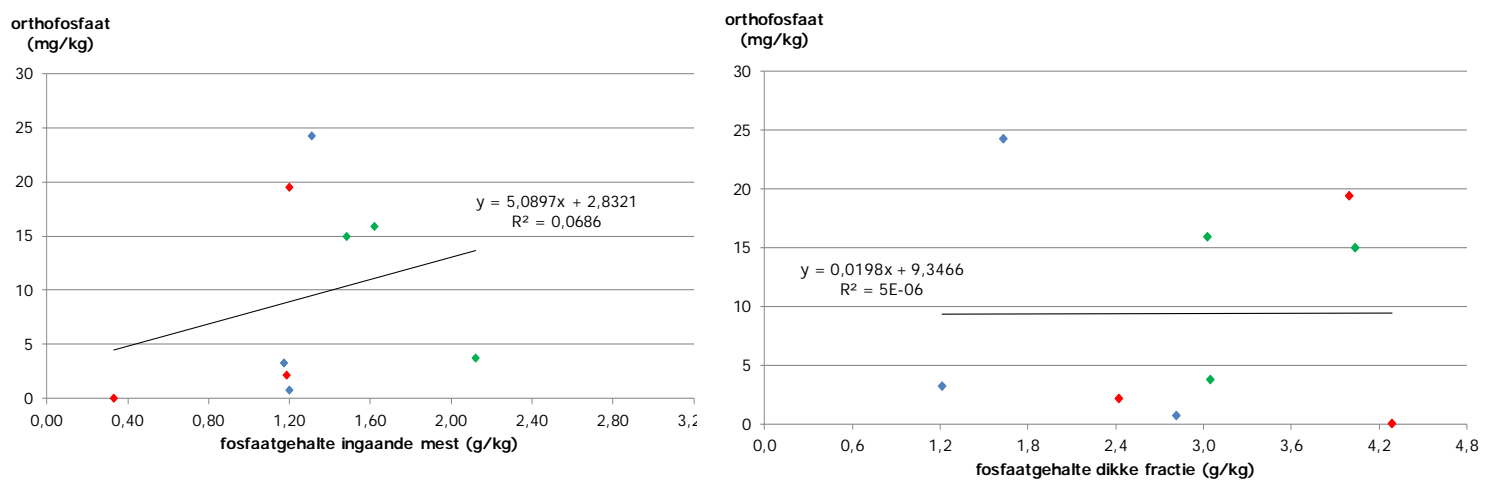

Figuur 4b Het orthofosfaat gehalte in de dikke fractie in relatie tot het fosfaatgehalte in de ingaande mest (links) en het fosfaatgehalte in de dikke fractie (rechts) (groen = vijzelpers; blauw = trommelscheider/rollenpers; rood = centrifuge).
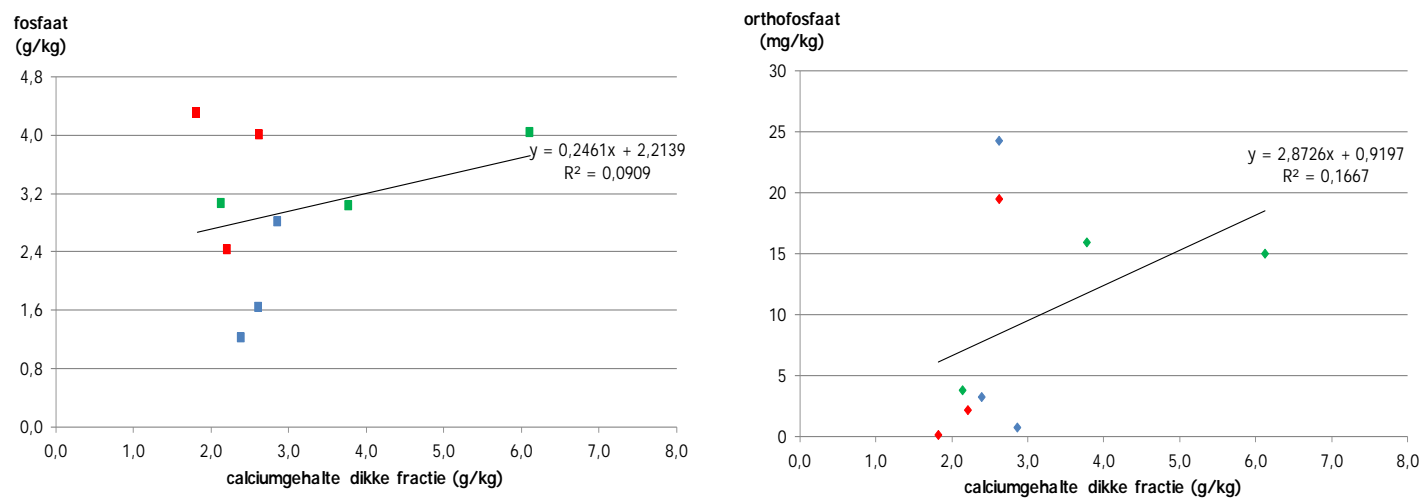

Figuur 4c Het fosfaat en orthofosfaat gehalte in de dikke fractie in relatie tot het calciumgehalte in de dikke fractie (groen = vijzelpers; blauw = trommelscheider/rollenpers; rood = centrifuge)
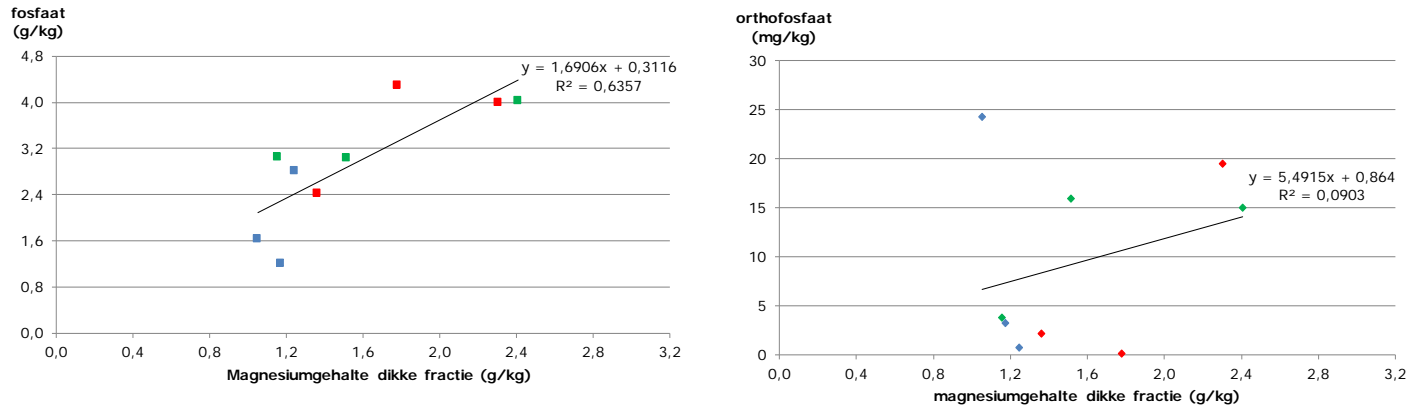

Figuur 4d Het fosfaat en orthofosfaat gehalte in de dikke fractie in relatie tot het magnesiumgehalte in de dikke fractie (groen = vijzelpers; blauw = trommelscheider/rollenpers; rood = centrifuge) 


\subsection{Samenstelling faeces}

In tabel 7 staan de analyseresultaten van de faeces die zijn verzameld via uitmestsystemen weergegeven.

Tabel 7 Analyseresultaten van de faeces verzameld door uitmestsystemen per kg product.

\begin{tabular}{|c|c|c|c|c|c|c|c|c|}
\hline Bedrijf & Scheider & $\begin{array}{c}\text { DS } \\
(\mathrm{g} / \mathrm{kg})\end{array}$ & $\begin{array}{c}\text { OS } \\
(\mathrm{g} / \mathrm{kg})\end{array}$ & $\begin{array}{c}\mathrm{P}_{2} \mathrm{O}_{5} \\
(\mathrm{~g} / \mathrm{kg})\end{array}$ & $\begin{array}{l}\text { Ortho- } \mathrm{P}_{2} \mathrm{O}_{5} \\
\text { ( } \mathrm{mg} / \mathrm{kg} \text { ) }\end{array}$ & $\begin{array}{l}\text { N-totaal } \\
\text { (g/ kg) }\end{array}$ & $\begin{array}{c}\mathrm{Ca} \\
(\mathrm{g} / \mathrm{kg})\end{array}$ & $\begin{array}{c}M g \\
(\mathrm{~g} / \mathrm{kg})\end{array}$ \\
\hline K & Mestschuif & 142 & 117 & 2,07 & 93,9 & 4,79 & 2,89 & 1,34 \\
\hline M-melk ${ }^{1)}$ & Mestrobot & 162 & 123 & 2,98 & 67,0 & 4,85 & 2,64 & 1,71 \\
\hline M-droog ${ }^{1)}$ & Mestrobot & 154 & 128 & 2,51 & 34,9 & 4,19 & 1,79 & 2,06 \\
\hline
\end{tabular}

1) Op bedrijf $\mathrm{M}$ zijn monsters genomen van de mestrobot bij de melkgevende en droge koeien.

De tabel laat de volgende variatie in gehalten zien in de faeces: fosfaat van 2,07 tot $2,98 \mathrm{~g} / \mathrm{kg}$, orthofosfaat van 34,9 tot $93,9 \mathrm{mg} / \mathrm{kg}$, aandeel van orthofosfaat t.o.v. totaal fosfaat van 1,4 tot $4,5 \%$, stikstof van 4,06 tot $4,85 \mathrm{~g} / \mathrm{kg}$, calcium van 1,79 tot $2,89 \mathrm{~g} / \mathrm{kg}$ en magnesium van 1,19 tot $2,06 \mathrm{~g} / \mathrm{kg}$.

In figuren 5a t/m c staan de belangrijkste relaties m.b.t. fosfaat, orthofosfaat, calcium en magnesium gehalte in de faeces weergegeven met indicatieve trendlijnen waarbij opgemerkt dient te worden dat het om een klein aantal bedrijven gaat. Er lijkt geen relatie te zijn tussen het orthofosfaat gehalte en het fosfaatgehalte in de faeces op zowel product als droge stof basis. Het betreft maar een beperkt aantal bedrijven en de spreiding in orthofosfaat is te groot. Tussen het fosfaatgehalte en het calciumen magnesiumgehalte lijkt er ook geen verband te zijn. Echter er lijkt wel een verband te zijn voor het orthofosfaat gehalte in de faeces in relatie tot het calcium- en magnesiumgehalte in de faeces. Hoe hoger het calciumgehalte, hoe hoger het orthofosfaat gehalte en hoe hoger het magnesiumgehalte, hoe lager het orthofosfaat gehalte was in de faeces. 

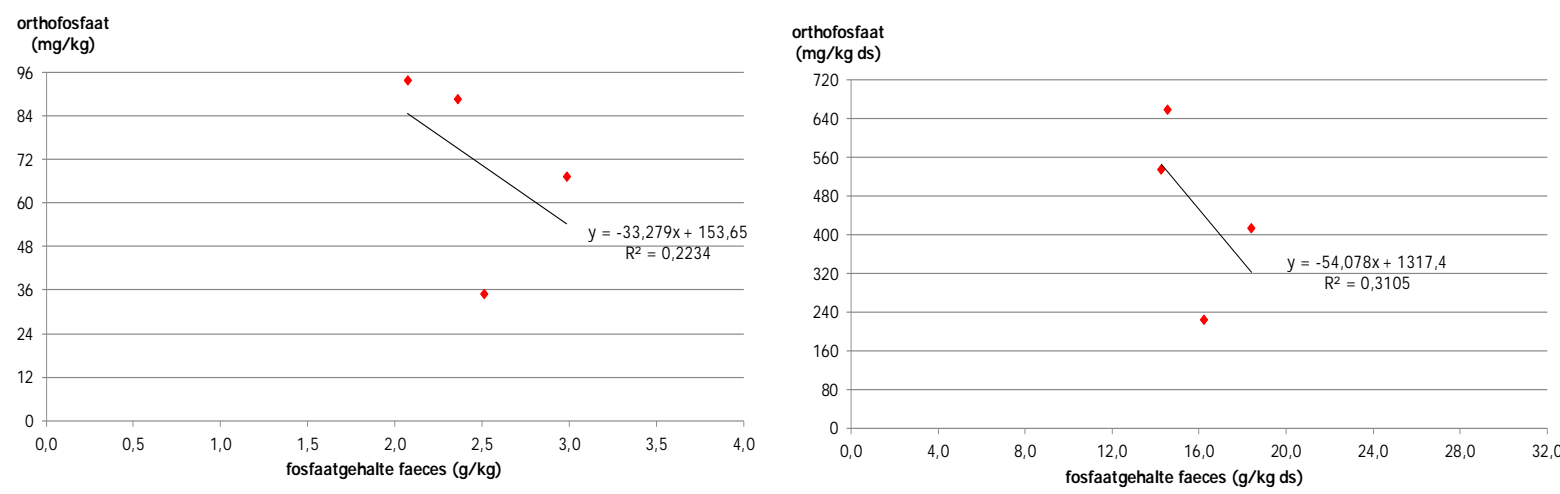

Figuur 5a Het orthofosfaat gehalte in relatie tot het fosfaatgehalte in de faeces op product en droge stof basis.
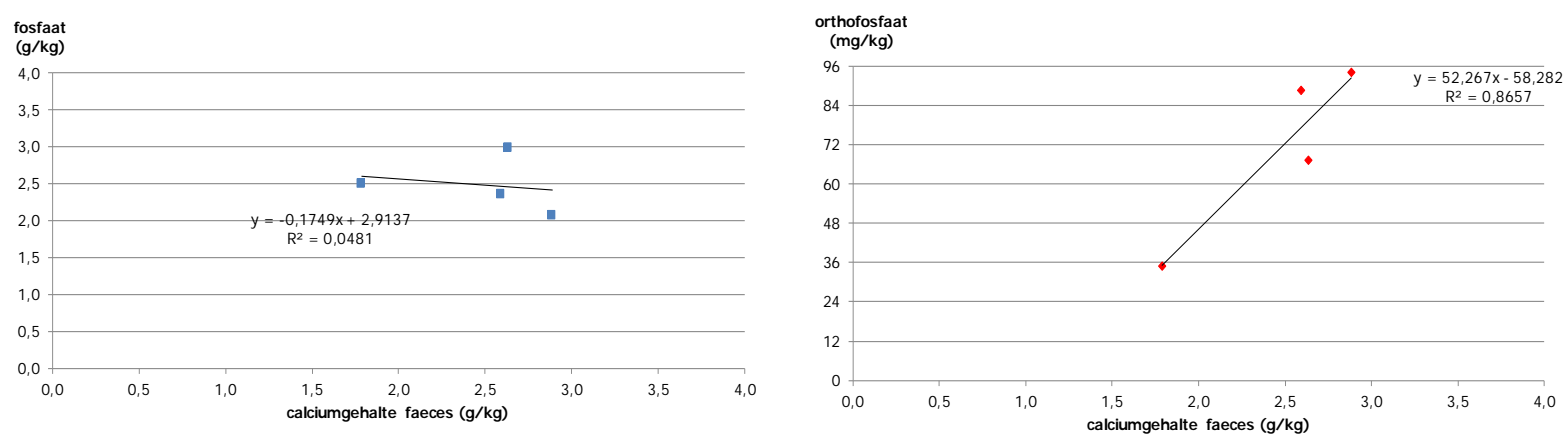

Figuur 5b Het fosfaat en orthofosfaat gehalte in de faeces in relatie tot het calciumgehalte in de faeces.
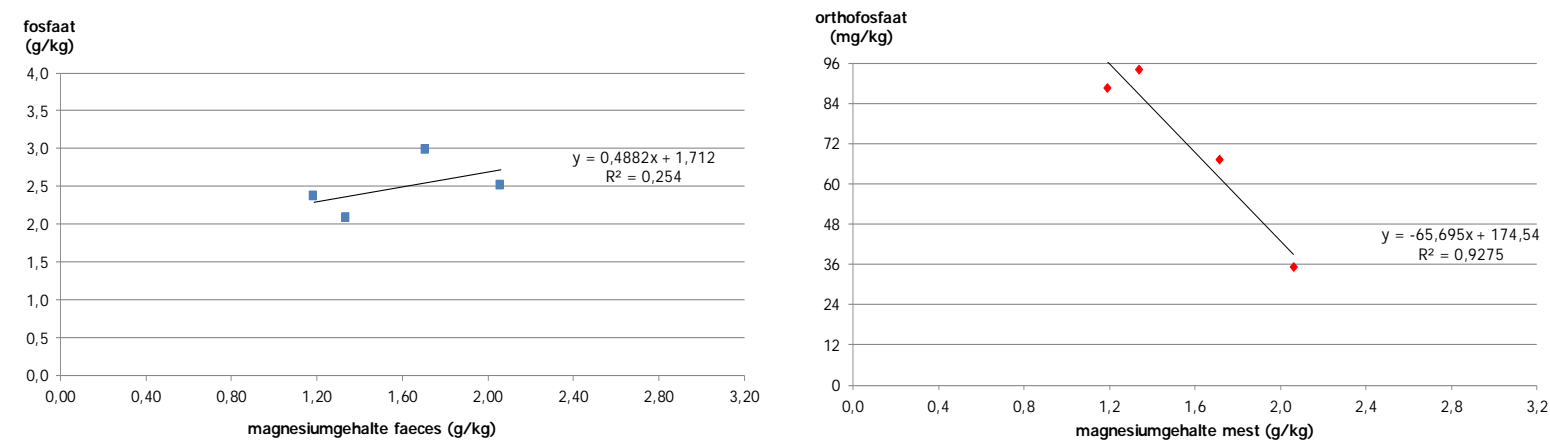

Figuur 5c Het fosfaat en orthofosfaat gehalte in de faeces in relatie tot het magnesiumgehalte in de faeces. 


\subsection{Terugwinning van fosfaat uit de dunne fractie}

In tabel 8 staan de analyseresultaten van de dunne fractie en gescheiden fracties na toedienen van calciumhydroxide aan de dunne fractie met de scheidingsrendementen weergegeven.

Tabel 8 Analyseresultaten van de dunne fractie en gescheiden fracties na toedienen van calciumhydroxide aan de dunne fractie met de scheidingsrendementen.

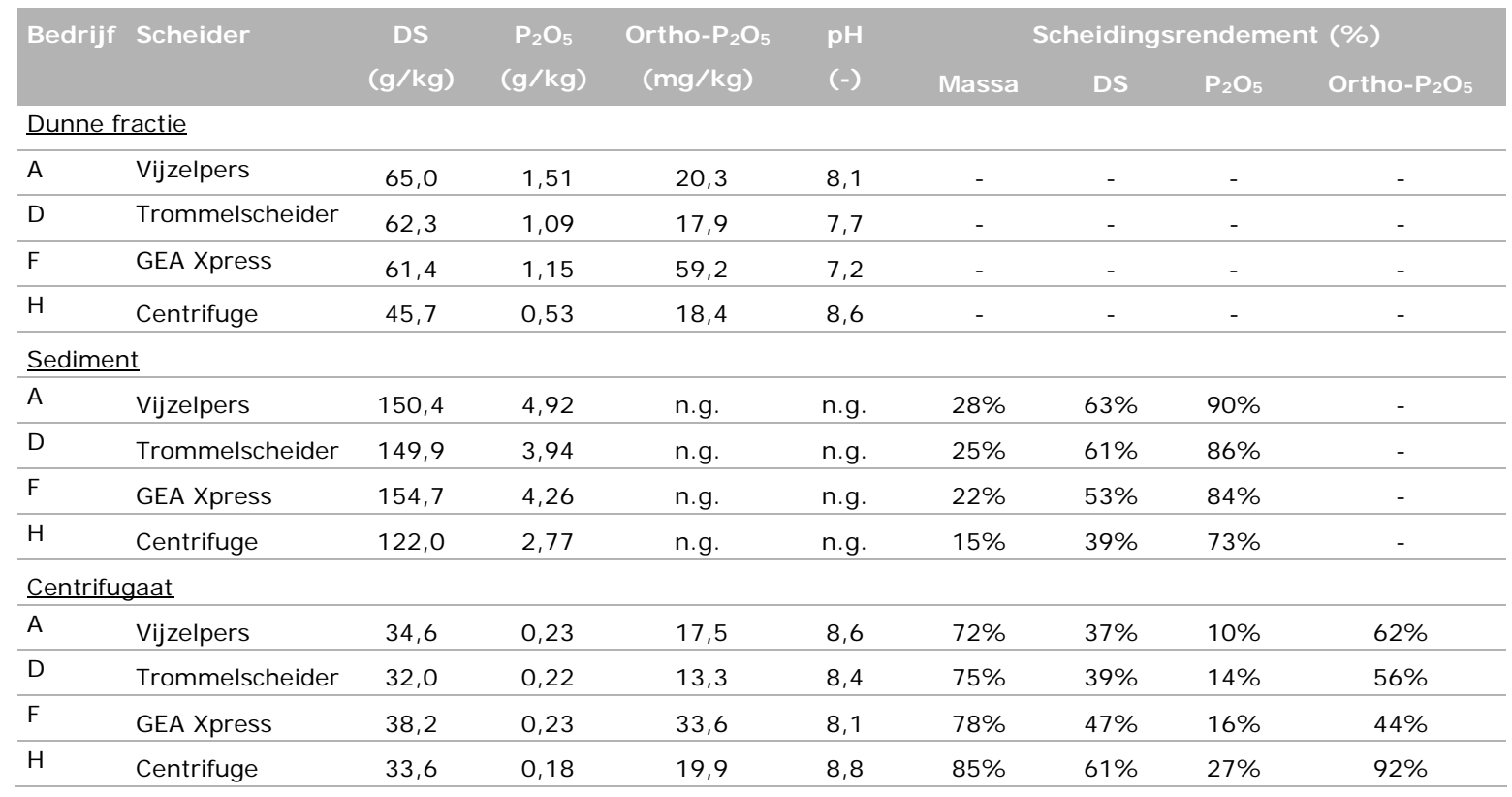

n.g. = niet gemeten .

De resultaten laten zien dat gemiddeld $23 \%$ van de massa en $54 \%$ van de drogestof terechtkwam in het sediment. De toevoeging van calciumhydroxide heeft geleid tot lagere fosfaatgehalten in het centrifugaat en hogere fosfaatgehalten in het sediment t.o.v. de dunne fractie. Gemiddeld kwam 83\% van het totale fosfaat uit de dunne fractie in het sediment terecht. Van het totale orthofosfaat uit de dunne fractie kwam gemiddeld $64 \%$ terecht in het centrifugaat en daarmee $36 \%$ in het sediment. Dit is $13 \%$ hoger dan het scheidingsrendement voor de massa wat betekent dat een klein deel van het orthofosfaat met calcium heeft gereageerd en als calciumfosfaat in het sediment terecht is gekomen.

Tabel 9 toont de fosfaatgehalten in de dikke fractie, dunne fractie en het sediment per kilogram product. Het fosfaatgehalte in het sediment ligt meer dan $50 \%$ dan in de dikke fracties afkomstig van de relatief eenvoudige mestscheiders, maar $44 \%$ lager dan in de dikke fractie van de centrifuge.

Tabel 9 Fosfaatgehalten in dikke fractie, dunne fractie en het sediment verkregen na calciumhydroxide toevoeging in $\mathrm{P}_{2} \mathrm{O}_{5}$ per $\mathrm{kg}$ product.

\begin{tabular}{llcccc} 
Bedrijf & Scheider & Dikke fractie & Dunne fractie & Sediment \\
& & $(\mathrm{g} / \mathrm{kg})$ & $(\mathrm{g} / \mathrm{kg})$ & $(\mathrm{g} / \mathrm{kg})$ & 4,92 \\
\hline $\mathrm{A}$ & Vijzelpers & 3,03 & 1,51 & 3,94 \\
\hline $\mathrm{F}$ & Trommelscheider & 1,63 & 1,09 & 4,15 & 4,26 \\
\hline $\mathrm{F}$ & Rollenpers & 2,81 & 0,53 & 2,77 & \\
\hline
\end{tabular}




\subsection{Terugwinning van fosfaat uit de dikke fractie}

In figuur 6 staan de resultaten van de zuurtitratie curves waarbij de dikke mestfractie is aangelengd met water tot $6 \%$ drogestof en met zwavelzuur is aangezuurd tot $\mathrm{pH} 6$ en pH 5 waarna de waterfase is afgescheiden voor analyse. De figuren tonen het aandeel van fosfaat, orthofosfaat, calcium en magnesium in de waterfase na aanzuren van het totale gehalte in de dikke fractie. Na het verdunnen met water bedroeg het aandeel orthofosfaat 1 tot $8 \%$. Bij aanzuren tot pH 6 neemt het aandeel orthofosfaat sterk toe, naar 40 tot $59 \%$. Bij verder aanzuren tot pH 5 neemt het aandeel verder toe, naar 42 tot $68 \%$. Het aandeel fosfaat in de waterfase toont een vergelijkbaar beeld. $\mathrm{Na}$ aanzuren maakt orthofosfaat voor 80 tot $96 \%$ deelt uit van het totale fosfaat.
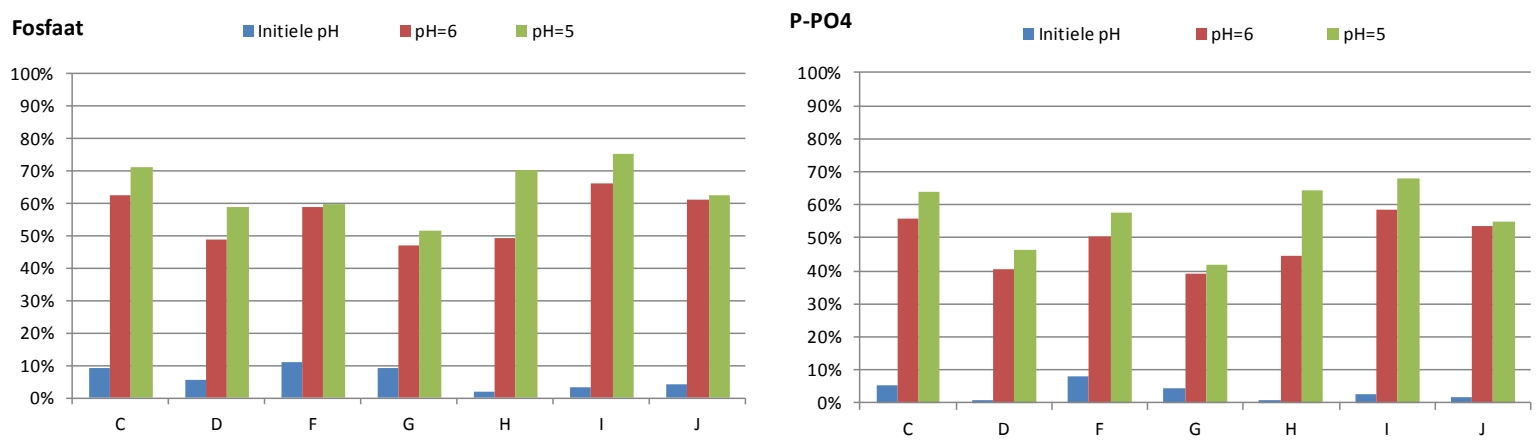

Figuur 6a Het aandeel fosfaat (links) en orthofosfaat (rechts) in de waterfase van het totale fosfaat in de dikke fractie bij initiële pH en bij aanzuren tot pH 6 en 5.
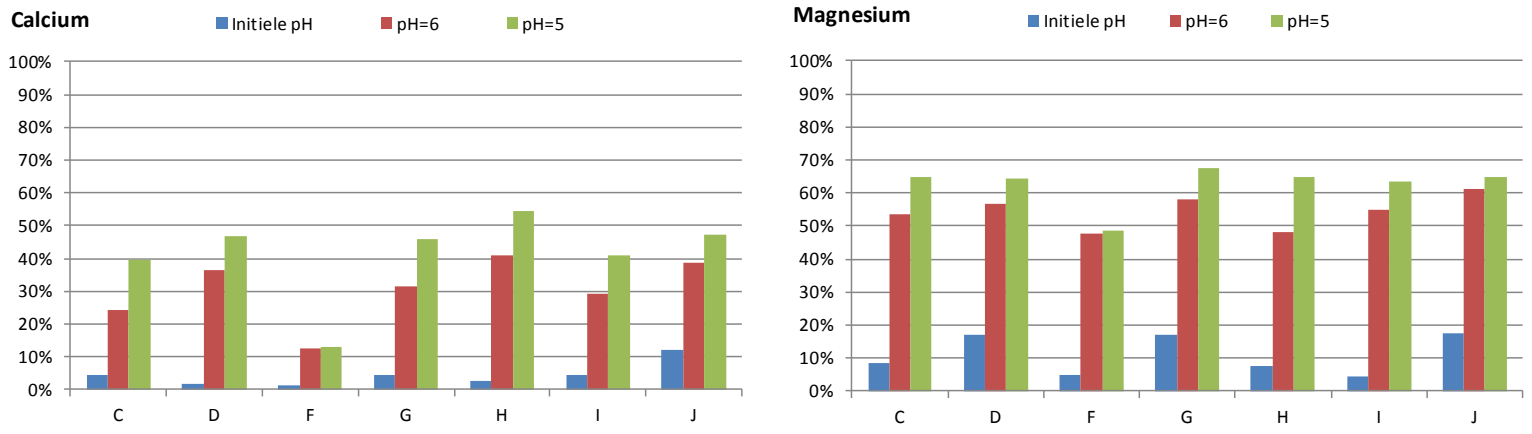

Figuur 6b Het aandeel calcium (links) en magnesium (rechts) in de waterfase van het totale calcium en magnesium in de dikke fractie bij initiële pH en bij aanzuren tot pH 6 en 5.

Aanzuren leidt eveneens tot een sterke toename van het aandeel calcium en magnesium in de waterfase. Dit duidt op het oplossen van calcium- en magnesiumfosfaat mineralen bij het aanzuren van de dikke fractie. Op basis van de molaire ratio's tussen orthofosfaat en de divalente kationen in de waterfase is getracht af te leiden of fosfaat in de dikke fractie voornamelijk gebonden is aan calcium of magnesium. Dit kan echter niet worden afgeleid omdat zowel calcium als magnesium in overmaat aanwezig zijn t.o.v. orthofosfaat. Fosfaat in de dikke fractie kan dus zowel voorkomen in de vorm van magnesiumfosfaat als calciumfosfaat.

Tabel 10 toont de benodigde zuurdosering voor het aanzuren van dikke fractie mest en de bijbehorende hoeveelheid fosfaat welke in oplossing wordt gebracht. Het aanzuren van dikke fractie mest tot pH 5 vraagt om een zuurdosering van 8 tot $18 \mathrm{~kg} \mathrm{H}_{2} \mathrm{SO}_{4}$ per ton dikke fractie. Bij deze dosering wordt 0.4 tot $2.7 \mathrm{~g} / \mathrm{kg}$ fosfaat in oplossing gebracht. De netto zuurdosering per mol orthofosfaat bedraagt 6 tot $24 \mathrm{~mol} \mathrm{H}^{+}$en neemt toe met een afnemend fosfaatgehalte in de dikke mest. 
Tabel 10 Zuurdosering en hoeveelheid in oplossing gebracht orthofosfaat na aanzuren van dikke fractie mest tot $\mathrm{pH} 5$.

\begin{tabular}{|c|c|c|c|c|c|}
\hline Bedrijf & Scheider & $\begin{array}{l}\text { Zuurdosering } \\
\text { ( } \mathrm{kg} \mathrm{H}_{2} \mathrm{SO}_{4} / \text { ton) }\end{array}$ & $\begin{array}{c}\text { P-extractie } \\
(\%)\end{array}$ & $\begin{array}{l}\text { P-extractie } \\
\text { (g/ kg) }\end{array}$ & 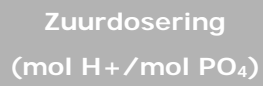 \\
\hline C & Vijzelpers & 10 & 52 & 1.6 & 9 \\
\hline$D$ & Trommelscheider & 12 & 40 & 0.6 & 27 \\
\hline $\mathrm{F}$ & GEA Express & 10 & 52 & 1.5 & 9 \\
\hline G & GEA Express & 8 & 44 & 0.4 & 24 \\
\hline $\mathrm{H}$ & Centrifuge & 18 & 61 & 2.3 & 10 \\
\hline I & Centrifuge & 11 & 64 & 2.7 & 6 \\
\hline
\end{tabular}




\section{$4 \quad$ Discussie}

Een standaard meetprotocol voor de bepaling van orthofosfaat in mestmonsters ontbreekt vooralsnog. Daarom zijn de resultaten van drie analysemethoden met elkaar vergeleken. Analysemethode 1, waarbij de waterfase door middel van centrifugeren werd afgescheiden, gaf het meest betrouwbare meetresultaat. Deze methode is echter bewerkelijk omdat de mestmonsters drie maal bij hoge snelheid gecentrifugeerd moeten worden. Omdat er bij deze methode niet wordt gefiltreerd is het van belang om een helder monster te verkrijgen zodat overschatting van orthofosfaat door de aanwezigheid van colloïdaal fosfaat wordt voorkomen. Analysemethode 1 kon niet worden toegepast op monsters van de dikke fractie. Bij analysemethode 2 werd mest met water gemengd waarna orthofosfaat werd gemeten in het filtraat. Deze methode is aanzienlijk sneller en eenvoudiger, waarbij het van belang is om de gemeten concentratie in het extract te rapporteren ('evenwichtsconcentratie') zonder deze terug te rekenen naar de ingewogen hoeveelheid mest. Deze methode is echter niet generiek toepasbaar omdat de achterliggende aanname (de evenwichtsconcentratie in de mest is gelijk aan de evenwichtsconcentratie in het extract) niet per definitie geldig is in matrices met een andere samenstelling dan mest zoals zuiveringsslib. Methode 3 bestond uit een combinatie van centrifugeren, verdunnen van het supernatant en analyse van orthofosfaat in het filtraat. Deze methode gaf vergelijkbare resultaten als methode 1 .

De type scheider bepaalt in welke mate het fosfaat terechtkomt in de dikke fractie en welke daling in het fosfaatgehalte in de dunne fractie wordt gehaald. Bij de eenvoudige scheiders zoals de vijzelpers, trommelscheider en rollenpers komt circa 20 tot $40 \%$ van de fosfaat terecht in de dikke fractie en lijkt de samenstelling van de dunne fractie nog veel op de ingaande drijfmest, terwijl bij centrifuges circa 60 tot $70 \%$ van de fosfaat in de dikke fractie terechtkomt (Schröder et al., 2009). In het uitgevoerde onderzoek lag het fosfaatgehalte in dunne fracties van de eenvoudige scheiders gemiddeld $12 \%$ lager dan in de ingaande drijfmest, terwijl bij de centrifuge het fosfaatgehalte gemiddeld $37 \%$ lager lag. Het fosfaatgehalte in de dikke fractie vertoonde een grote variatie tussen de bedrijven waardoor geen verband tussen scheidingstechniek en fosfaatgehalte in de dikke fractie zichtbaar werd.

Het fosfaatgehalte in de dunne fracties varieerde van 0,25 tot $1,88 \mathrm{~g} / \mathrm{kg}$. De orthofosfaat gehalten in de dunne fracties varieerde van 0,1 tot $30 \mathrm{mg} / \mathrm{L}$. Orthofosfaat bedraagt daarmee minder dan $4 \%$ van het totale fosfaat in de dunne fractie. De lage orthofosfaat gehalten kunnen worden verklaard door vastlegging van orthofosfaat met calcium en magnesium wat bij deze pH-waarden $(6,8-7,6)$ neerslaat in de vorm van calciumfosfaat, magnesiumfosfaat en/of struviet. De dunne mest bevat voldoende calcium en magnesium om alle fosfaat te binden. Nadere analyse van de fosfaatvormen in de dunne mestfractie wees inderdaad uit dat fosfaat voor het overgrote deel (43-81\%) aanwezig is in de vorm van zuur oplosbaar, mineraal fosfaat (i.e. calciumfosfaat, magnesiumfosfaat) en voor een kleiner deel (18-53\%) in vorm van organisch fosfaat (o.a. fytaat).

In de literatuur zijn slechts enkele studies gevonden waarin orthofosfaat is bepaald in mest(fracties) of digestaat van mest. In onderzoek van LeAF naar struvietwinning uit dunne fractie varkensmest wordt een orthofosfaat waarde van $400 \mathrm{mg} / \mathrm{L}$ gerapporteerd, echter de gehanteerde methode is niet beschreven (Eekert et al., 2013). Huchzermeier et al., (2012) rapporteert een gehalte orthofosfaat in de dunne fractie van rundermest-digestaat van $209 \mathrm{mg} / \mathrm{L}$. De beschreven methode komt overeen met analysemethode 1 uit deze rapportage. De studie geeft echter weinig gegevens omtrent de samenstelling en herkomst waardoor het niet mogelijk is om een verklaring te vinden voor de beduidende hogere orthofosfaat concentraties. In dunne fractie van varkensmest zijn orthofosfaat gehalten gemeten van $18 \mathrm{mg} / \mathrm{l}$ wat overeenkomt met minder dan 1\% van het totale fosfaat (Schoumans et al., 2017) en daarmee in lijn is met deze studie. Voor zuiveringsslib zijn meer gegevens beschikbaar en worden orthofosfaat gehalten ten hoogte van $20-40 \%$ van totaal fosfaat gemeten (Marti et al., 2008; Regelink et al., 2017) wat verklaard kan worden door de lagere calcium gehalten waardoor minder fosfaat kan precipiteren. 
Menezes-Blackburn et al. $(2014 ; 2016)$ hebben onderzoek gedaan naar het toevoegen van fytase aan de mest om organische gebonden fosfaat om te zetten naar anorganische fosfaat. In beide studies werd gebruik gemaakt van de Bacillus sp. MQH-19 stam die extracellulaire beta-propeller fytase kan produceren onder basische condities. Na voorbehandeling werd de mest geïncubeerd met de Bacillus sp MQH-19 voor 6 dagen bij $30^{\circ} \mathrm{C}$ en vervolgens geanalyseerd. In beide studies nam het gehalte aan anorganische fosfaat toe met circa $10 \%$. Gezien de relatief beperkte stijging van het anorganische fosfaatgehalte en het feit dat het vrijkomende anorganische fosfaat vermoedelijk ook zal neerslaan met in de mest aanwezige calcium en magnesium, lijkt het gebruik van fytase om het orthofosfaat gehalte in mest te verhogen niet perspectiefvol.

$\mathrm{Na}$ dosering van calciumhydroxide aan de dunne fractie van de mest gevolgd door centrifugeren bevond circa $86 \%$ van het fosfaat zich in het sediment. Bij deze testen was geen controle-behandeling zonder calcium-dosering gedaan, vanwege beperkingen in de praktische uitvoering waarbij maar twee monsters per keer konden worden ingezet. Mogelijk dat als er alleen was gecentrifugeerd er vergelijkbare uitkomsten waren behaald aangezien het scheidingsrendement voor fosfaat niet veel hoger was dan het scheidingsrendement van de massa. Het is via deze route dus niet mogelijk om een minerale meststof met een laag organisch stof gehalte terug te winnen. Terugwinnen van fosfaat uit dunne fractie mest middels calcium dosering en centrifugeren biedt daarmee geen perspectief vanwege de zeer lage orthofosfaat gehalten en omdat met centrifugeren het minerale fosfaat niet gescheiden kan worden van de organische stof.

In de literatuur zijn enkele studies gevonden waarin een vergelijkbare methode, maar dan met dosering van magnesium, is getest op dunne fractie van varkensmest. Schoumans et al. (2017) onderzocht de perspectieven voor terugwinning van fosfaat uit de dunne fractie van varkensmest door dosering van magnesium. In deze studie werd geconcludeerd dat er onvoldoende struviet vorming optreedt en terugwinning uit de dunne fractie daarom geen perspectief biedt. In een eerdere studie van Eekert et al. (2014) wordt eveneens geconcludeerd dat er bij dosering van magnesium aan dunne fractie van varkensmest vrijwel geen struviet vorming optreedt. Dergelijke technieken, welke goed werken bij stromen met een hoog orthofosfaat gehalte (o.a. zuiveringsslib), blijken dus niet toepasbaar op dunne mest vanwege de te lage orthofosfaat gehalten.

Het scheiden van de dikke fractie in een minerale fosfaatmeststof en een fosfaatverarmde organische meststof is mogelijk door de dikke fractie aan te zuren en vervolgens het vrijgekomen orthofosfaat terug te winnen door dosering van een base. De benodigde zuurdosering bedraagt 8- $12 \mathrm{~kg} \mathrm{H}_{2} \mathrm{SO}_{4} /$ ton mest. Omdat het fosfaatgehalte in dikke fractie van rundermest relatief laag is in vergelijking met de dikke fractie van varkensmest zullen de kosten voor behandeling van rundermest per kg fosfaat hoger zijn dan bij behandeling van varkensmest. Dit blijkt wanneer de zuurdosering wordt uitgedrukt per mol winbaar fosfaat ( $8-26 \mathrm{~mol} / \mathrm{mol}$ ) en vergeleken wordt met de zuurdosering bij behandeling van dikke fractie van varkensmest $(6 \mathrm{~mol} / \mathrm{mol}$ ) (Schoumans et al., 2017). Voor vergiste varkensmest kan fosfaatterugwinning uit de dikke fractie digestaat naar verwachting economisch concurreren met de rechtstreekse afzet van varkensmest (Schoumans et al., 2017). Het is echter waarschijnlijk dat behandeling van de dikke fractie voor rundermest geen economische voordelen biedt omdat de afzetkosten voor rundermest lager zijn dan voor varkensmest. Rundermest kan immers tegen betaling goedgeplaatst worden in de akkerbouw. Daarbij is het terugwinnen van fosfaat uit dikke fractie van mest praktisch gezien niet toepasbaar op bedrijfsschaal en biedt zodoende uitsluitend mogelijkheden voor (regionale) mestverwerkers.

Op melkveebedrijven wordt voornamelijk gebruikt gemaakt van relatief eenvoudige mestscheiders waarbij 20 tot $40 \%$ van de fosfaat in de dikke fractie terechtkomt wat het potentieel voor terugwinning van fosfaat beperkt. Inzet van centrifuges vergroot het aandeel fosfaat in de dikke fractie naar 60 tot $70 \%$. Echter, het overgrote deel van de melkveehouders heeft eigen land waarop mest wordt uitgereden voor bemesting. Bij te grote afscheiding van fosfaat in de dikke fractie en afvoer van de dikke fractie betekent dat te weinig fosfaat resteert voor bemesting van het eigen land. Daarbij is de dikke fractie uit eenvoudige mestscheiders beter geschikt om in te zetten als strooisel in de ligboxen. Dit verklaart naast de lagere kosten waarom eenvoudige mestscheiders gebruikt worden op melkveebedrijven. Wanneer maar een beperkt deel van het fosfaat afgevoerd hoeft te worden is het daarom niet interessant om te investeren in meer geavanceerde mestscheiders. 


\section{Conclusies}

- Het fosfaatgehalte in de dikke fracties uit de mestscheiders varieerde van 1,21 tot 4,29 g/ $\mathrm{kg}$ en was hoger in dikke fractie van de centrifuge dan van de eenvoudigere mestscheiders. Het fosfaatgehalte in de dunne fracties uit de mestscheiders varieerde van 0,25 tot 1,88 g/ kg, waarbij de gehalten in de dunne fracties afkomstig van de centrifugeren het laagst warend.

- Het aandeel orthofosfaat in de drijfmest, dikke fracties en faeces maakte een klein deel $(<8 \%)$ uit van de totale hoeveelheid fosfaat.

- Het aandeel orthofosfaat in de dunne fractie was minder dan $4 \%$ van de totale hoeveelheid fosfaat. Het aandeel mineraal fosfaat varieerde van 43 tot $81 \%$ van de totale fosfaat in de dunne fractie en organische fosfaat voor 18 tot $53 \%$.

- Na toevoeging van calciumhydroxide aan de dunne fracties en centrifugeren kwam $23 \%$ van de massa, $54 \%$ van de drogestof, $83 \%$ van het totaal fosfaat en $36 \%$ van de orthofosfaat terecht in het sediment.

- Door de dikke fractie te verdunnen tot $6 \%$ drogestof en aan te zuren tot pH 6 komt 40 tot $59 \%$ van de totale hoeveelheid fosfaat beschikbaar als orthofosfaat. Dit aandeel neemt toe naar $42 \%$ tot $68 \%$ bij verder aanzuren tot $\mathrm{pH} 5$.

- Het potentieel voor winning van fosfaat uit de drijfmest, faeces, dunne of dikke fractie is laag vanwege de lage orthofosfaat gehalten in deze mestsoorten. Het potentieel kan worden verhoogd door verdunnen en/of aanzuren van de mestfracties waardoor additioneel orthofosfaat vrijkomt uit de minerale fosfaatverbindingen. 


\section{Literatuur}

Eekert, van, M., J. Weijma, E. Schuman, 2013. Magnesium, struviet, ontwatering van slib en mest verkenning van de toepassing diverse Mg-zouten. LeAf-rapport 12804

Goselink, R.M.A., G. Klop, J. Dijkstra,s A. Bannink, 2016. Phosphorus metabolism in dairy cattle - A literature study on recent developments and gaps in knowledge. Livestock Research Report 910. Wageningen UR Livestock Research, Wageningen, The Netherlands.

Huchzermeier, M.P., W. Tao, 2012. Overcoming challenges to struvite recovery from anearobically digested dairy manure. Water Environment Research, 84-1

Koeijer, T.J., de, H.H. Luesink, H. Prins, 2017. Dieraantallen, mestproductie, mestmarkt en kosten mestafzet. Wageningen Economic Research, report 2017-002.

Marti, N., A. Bouzas, A. Seco, J. Ferrer, 2008. Struvite precipitation assessment in anaerobic digestion processes. Chemical engineering Journal 141, pp 67-74

Menezes-Blackburn, D., M.A. Jorquera, L. Gianfreda, R. Greiner, M. de la Luz Mora, 2014. A novel phosphorus biofertilization strategy using cattle manure treated with phytase-nanoclay complexes. Biology and Fertility of Soils 50 (4):583-592.

Menezes-Blackburn, D., N.G. Inostroza, L. Gianfreda, R. Greiner, M. L. Mora, M.A. Jorquera, 2016. Phytase-producing Bacillus sp. inoculation increases phosphorus availability in cattle manure. Journal of Soil Science and Plant Nutrition 16 (1): 200-210.

Moorleghem, van C., I. Six, F. Degryse, E. Smolders, R. Merckx, 2011. Effect of organic P forms and P present in inorganic colloids on the determination of dissolved $\mathrm{P}$ in environmental samples by the diffusive gradient in thin films technique, ion chromatography and colorimetry. Analitical Chemistry 83: 5317-5323

Regelink, I.C., P.A.I. Ehlert, P. Römkes, 2017. Perspectieven voor de afzet van (fosfaatverarmd) zuiveringsslib naar de landbouw. Wageningen, Wageningen Environmental Research, Report 2819.

Schoumans O.F., P.A.I. Ehlert, I.C. Regelink, J.A. Nelemans, W. van Tintelen, W.H. Rulkens, 2017. Chemical phosphorus recovery from animal manure and digestate: Laboratory and pilot experiments. Wageningen, Wageningen Environmental Research, Report 2849

Schröder, J.J., F.E. de Buisonjé, G.J. Kasper, N. Verdoes, K. Verloop, 2009. Mestscheiding: relaties tussen techniek, kosten, milieu en landbouwkundige waarde. Plant Research International, Wageningen. Rapport 287.

Van Middelkoop, J., W. van Dijk, H. van Reuler, F. de Ruijter en B. Smit. 2015. Fosforstromen door landbouw, industrie, huishoudens en afval. V-focus 12 (4):36-38. 


\section{Bijlage 1 Fosforstromen in Nederland}

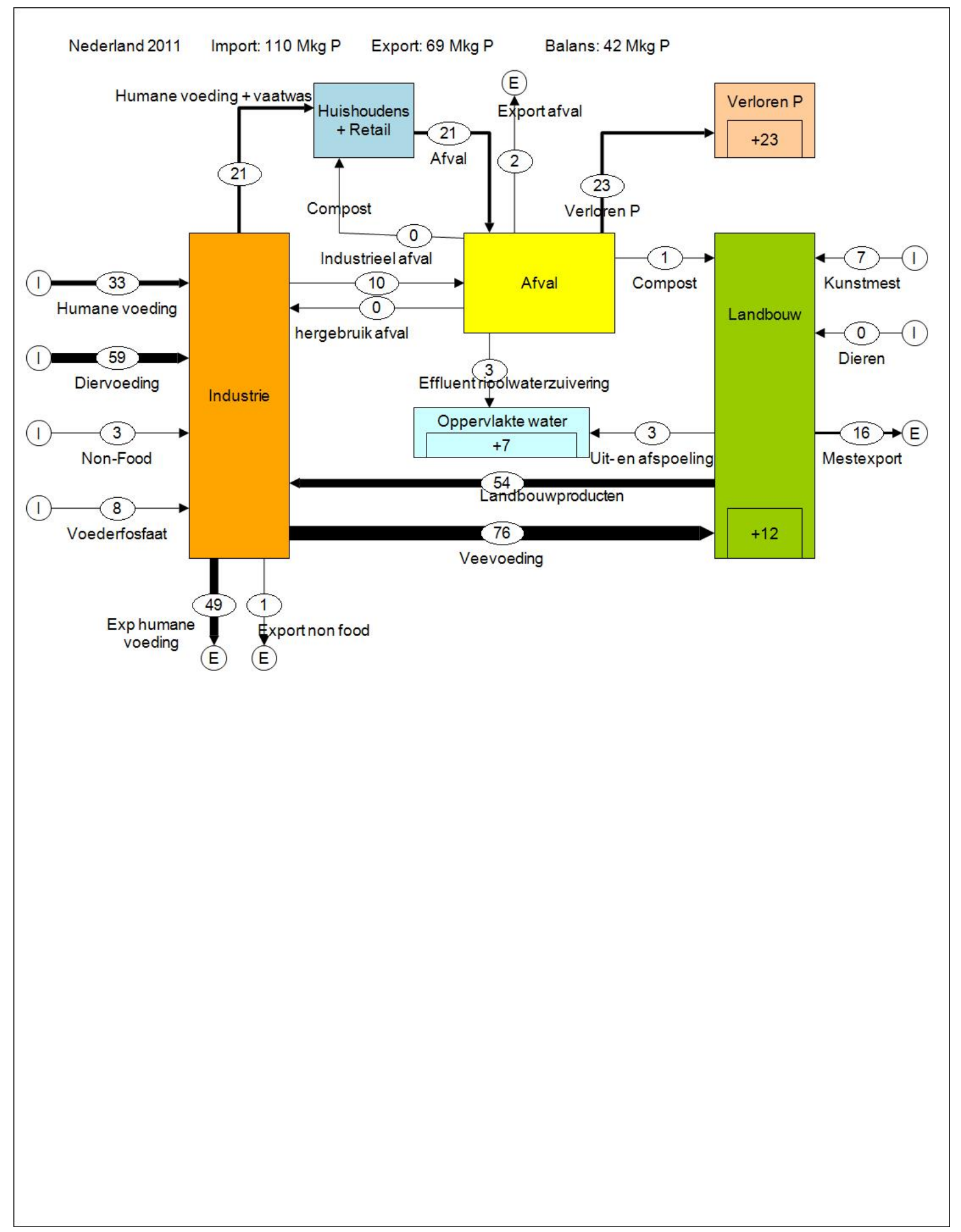

Figuur 1 Fosforstromen in industrie, landbouw, huishoudens, afval en oppervlaktewater in 2011 (miljoen kg P per jaar) (Van Middelkoop et al., 2015). 


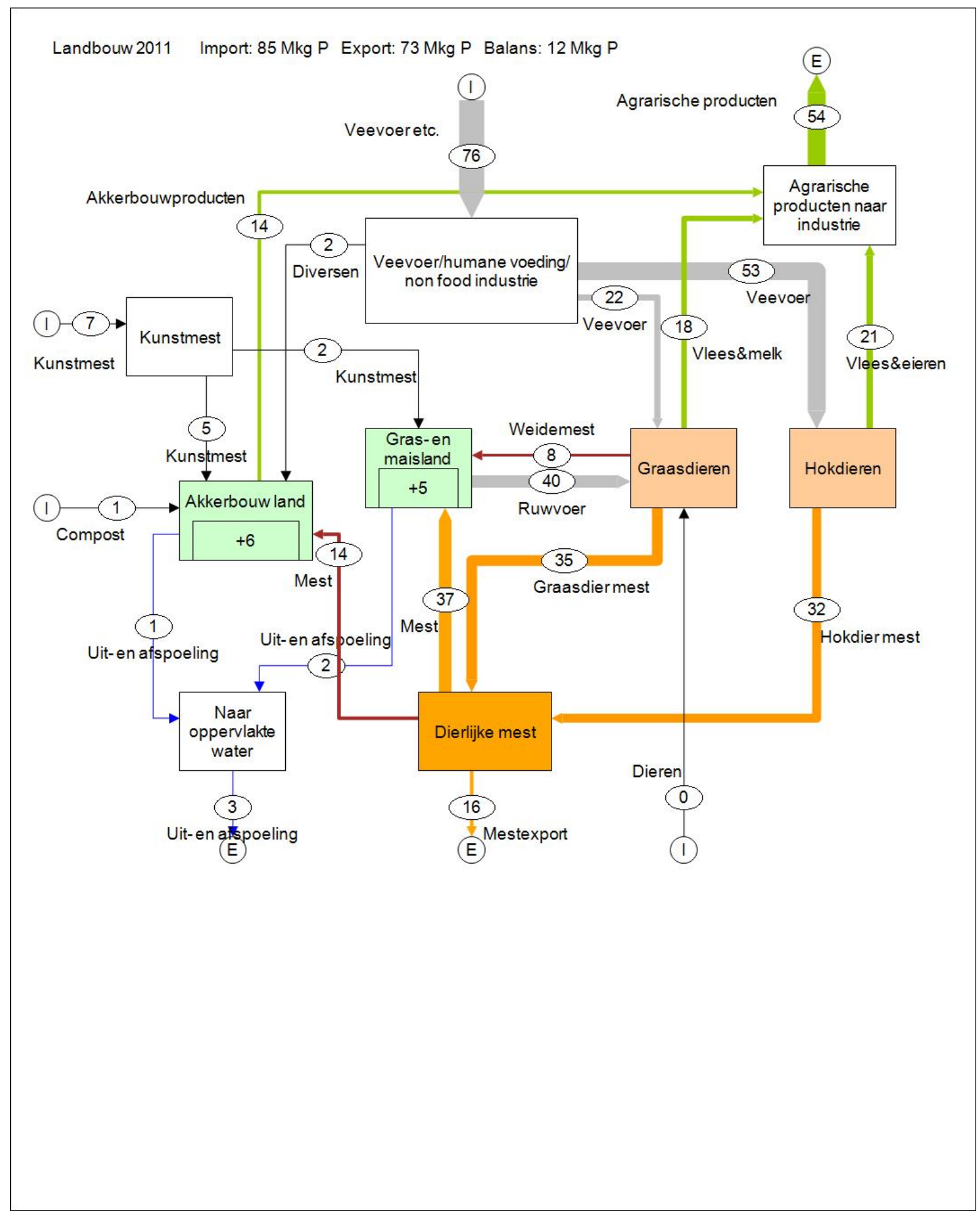

Figuur 2 Fosforstromen in de landbouw in 2011 (miljoen kg P per jaar) (Van Middelkoop et al., 2015). 

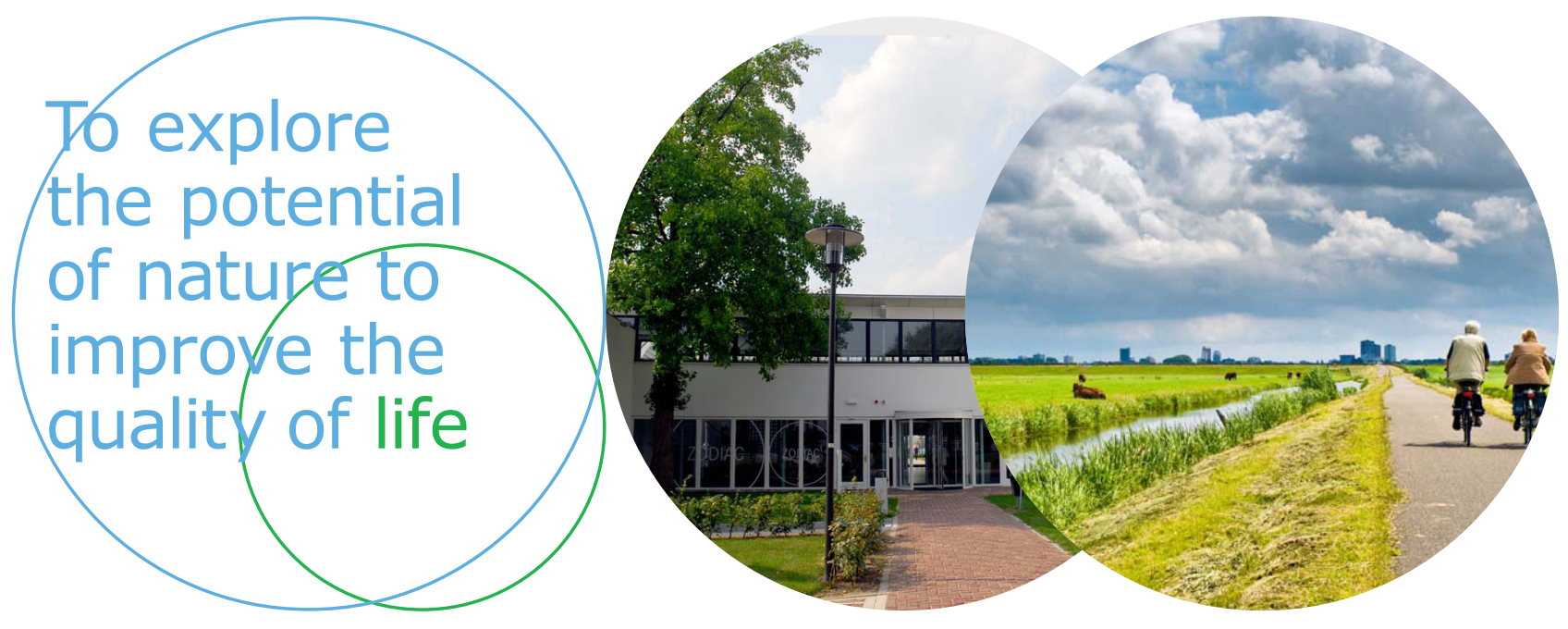

Wageningen Livestock Research Postbus 338

Wageningen Livestock Research ontwikkelt kennis voor een zorgvuldige en $6700 \mathrm{AH}$ Wageningen

T 0317483953

renderende veehouderij, vertaalt deze naar praktijkgerichte oplossingen en innovaties, en zorgt voor doorstroming van deze kennis. Onze wetenschappelijke E info.livestockresearch@wur.nl www.wur.nl/ livestock-research kennis op het gebied van veehouderijsystemen en van voeding, genetica, welzijn en milieu-impact van landbouwhuisdieren integreren we, samen met onze klanten, tot veehouderijconcepten voor de $21 \mathrm{e}$ eeuw.

De missie van Wageningen University \& Research is 'To explore the potential of nature to improve the quality of life'. Binnen Wageningen University \& Research bundelen 9 gespecialiseerde onderzoeksinstituten van Stichting Wageningen Research en Wageningen University hun krachten om bij te dragen aan de oplossing van belangrijke vragen in het domein van gezonde voeding en leefomgeving. Met ongeveer 30 vestigingen, 6.500 medewerkers en 10.000 studenten behoort Wageningen University \& Research wereldwijd tot de aansprekende kennisinstellingen binnen haar domein. De integrale benadering van de vraagstukken en de samenwerking tussen verschillende disciplines vormen het hart van de unieke Wageningen aanpak. 